NBER WORKING PAPER SERIES

\title{
PLAYING THE ADMISSIONS GAME: STUDENT REACTIONS TO INCREASING COLLEGE COMPETITION
}

\author{
John Bound \\ Brad Hershbein \\ Bridget Terry Long \\ Working Paper 15272 \\ http://www.nber.org/papers/w15272
}

\author{
NATIONAL BUREAU OF ECONOMIC RESEARCH \\ 1050 Massachusetts Avenue \\ Cambridge, MA 02138 \\ August 2009
}

We are grateful to Arline Geronimus, Dan Silverman and Sarah Turner for helpful discussions; to Jesse Rothstein, DeForest McDuff and Amanda Pallais for providing tabulations from SAT and ACT data on score sending behavior, and Sarah Turner for providing tabulations of the Survey of Earned Doctorates. This work was started while Bound was a fellow at that Center for Advanced Study in the Behavioral Science, Stanford University. The views expressed herein are those of the author(s) and do not necessarily reflect the views of the National Bureau of Economic Research.

NBER working papers are circulated for discussion and comment purposes. They have not been peerreviewed or been subject to the review by the NBER Board of Directors that accompanies official NBER publications.

(C) 2009 by John Bound, Brad Hershbein, and Bridget Terry Long. All rights reserved. Short sections of text, not to exceed two paragraphs, may be quoted without explicit permission provided that full credit, including $\odot$ notice, is given to the source. 
Playing the Admissions Game: Student Reactions to Increasing College Competition

John Bound, Brad Hershbein, and Bridget Terry Long

NBER Working Paper No. 15272

August 2009

JEL No. I2,J24

\begin{abstract}
$\underline{\text { ABSTRACT }}$
Gaining entrance to a four-year college or university, particularly a selective institution, has become increasingly competitive over the last several decades. We document this phenomenon and show how it has varied across different parts of the student ability distribution and across region, with the most pronounced increases in competition being found among higher-ability students and in the Northeast. Additionally, we explore how the college preparatory behavior of high school seniors has changed in response to the growth in competition. We also discuss the theoretical implications of increased competition on longer-term measures of learning and achievement and attempt to test them empirically; the evidence and related literature, while limited, suggests little long-term benefit.
\end{abstract}

\author{
John Bound \\ Department of Economics \\ University of Michigan \\ Ann Arbor, MI 48109-1220 \\ and NBER \\ jbound@umich.edu \\ Brad Hershbein \\ Department of Economics \\ University of Michigan \\ Ann Arbor, MI 48109-1220 \\ bjhersh@umich.edu
}

\author{
Bridget Terry Long \\ Harvard University \\ Graduate School of Education \\ Gutman Library 465 \\ 6 Appian Way \\ Cambridge, MA 02138 \\ and NBER \\ longbr@gse.harvard.edu
}




\section{INTRODUCTION}

During the last several decades, it has become increasingly difficult to gain entry into an American four-year college or university. Growing numbers of students fight for admission to such schools as the number of applicants has doubled since the early 1970s while school sizes have changed little. This increase is due both to the increasing fraction of high school graduates applying for college and more recently to the increase in the size of the college-aged cohorts. Using data from the Digest of Education Statistics and various National Center for Education Statistics (NCES) surveys, we summarize these trends in Table 1 . The table shows that while the application rate to four-year colleges has steadily increased over the last several decades, the decline in cohort size between 1982 and 1992 left the number of applicants practically unchanged between the two years. From 1992 to 2004, on the other hand, the number of applicants to four-year colleges grew from 1.19 million to 1.71 million students, an increase of 44 percent, as rising application rates and growing cohort size reinforced each other. The pattern was slightly different for selective private and public colleges, which saw the number of applicants rise by 10 to 15 percent over the 1980 s despite declining cohort size. While there was a slight dip in the application rate to selective privates between 1992 and 2004, this trend belies the fact that the number of applicants grew by 30,000, or 18 percent, due to growing cohort size.

Much of the increase in applications has been driven by female students. In 1972, the female ratio of first-year students at four-year schools was just under parity, but by 2004, the female share of students had risen to 55 percent. From 1972 to 1992, the growth in the number attending four-year colleges and universities came almost entirely from women as the number of men remained basically stable; since 1992, the growth in female applicants has continued to outpace male applicants. Overall, according to our calculations using data from the Digest of Education Statistics, the number of women applying to four-year colleges doubled between 1972 and 2004 while it increased by only 50 percent for men. The change in the female ratio of first-year students was even larger at selective private schools, where the share jumped from 42 percent to 52 percent over 30 years, with the fastest growth occurring since the 1980s. Not surprisingly, these trends are reflected in application patterns. 
At selective colleges and universities, applications from women nearly doubled while they increased by only 38 percent for men. At selective private and public schools, the number of men attending increased by less than 20 percent, while the number of women has risen by two-thirds.

In the face of growing demand, the supply of admission slots at four-year colleges did not keep pace. According to our calculations using data from the Annual Survey of Colleges, a nearcensus of four-year postsecondary institutions in the United States conducted by the College Board, the top 20 private universities and top 20 liberal arts colleges saw only a 0.7 percent change in average undergraduate enrollment from 1986 to 2003. Those ranked 21 to 50 also experienced relatively little growth (4.9 percent and 6.8 percent at private universities and liberal arts colleges, respectively). In contrast, other private four-year institutions grew nearly 16 percent during the period. There was more expansion at public institutions during this period with enrollments increasing 15.2 percent at the top 20 public universities, 10.5 percent at public universities ranked 21 to 47 , and 12.8 percent at other public institutions. This increase in enrollment at the most selective public institutions appears largely driven by transfer students, many assumed to be from public twoyear colleges. However, when focusing on the sizes of the incoming freshmen classes, the change in enrollment at public institutions has been much smaller. Because fewer than 500,000 slots were added in total at four-year schools from 1992 to 2004, supply did not keep pace with demand, and so college selectivity increased. High school seniors today are subject to more competition than at any time in the recent past.

The increased overall demand for a college education, presumably, can largely be explained by the dramatic increases in the value of such an education since the 1970s (Heckman, Lochner and Todd, 2006; Goldin and Katz, 2008). The increased demand for admission to selective schools in particular is plausibly related to the fact that the particular institution a student attends has become increasingly important. Since 1970, income distribution has widened among college-educated workers, and Hoxby and Long (1998) find that nearly half of the explained growth in this dispersion is due to the increasing concentration of peer and financial resources at more selective colleges and universities relative to other institutions. Other work has also documented this increasing 
segmentation within higher education (Hoxby, 1997, 2009; Bound, Lovenheim and Turner, 2008). The spread of information through the advent of the U.S. News and World Report (USNWR) and other rankings systems have also given students, their families, and society more data with which to evaluate college quality. As emphasized by Hoxby in this volume, the college market has shifted from one that is regional in focus to one that is national. It is also possible that as more workers are college educated, employers view the average college-educated worker as less productive than in the past. Under this signaling type of framework, a degree from an elite college becomes more valuable. All of these factors likely play a role in increasing the number of high school graduates who consider elite colleges.

This paper begins by documenting the trends of increasing competition in higher education, including how these increases have varied across certain groups, from the perspective of both institutions and students. It then explores the ways in which this phenomenon has influenced student behavior, in terms of academic preparation and high school activities, standardized test-taking, and college application behavior. Evidence from multiple sources suggests that a significant fraction of students are increasingly searching for ways to maximize their likelihood of admittance into a selective institution. As theory would predict, students have been driven to invest more in signals of ability and to raise their qualifications with the hope of increasing their chances of gaining entry into a selective institution. It has also driven students to alter their approaches to the college application. The extent of student reactions has differed along the ability distribution and by region, as the returns to such investments and changes in application approaches also vary by student. Finally, the paper explores whether such student reactions to growing competition have translated into longer-term effects on the amount that students learn. From a theoretical point of view, the increased competition could have induced high school students to work harder and learn more, or, alternatively, could have lead to the reverse by prompting investments in non-productive signals. Credible evidence on the net effect of increased competition is, needless to say, difficult to find. However, comparisons across regions of the country where competition is more versus less severe provides little evidence that 
increased competition has had positive effects on what students learn, and some suggestive evidence that the reverse might even be true.

\section{INCREASING COLLEGE SELECTIVITY}

\section{Institutional-level Indicators}

Changes in the percentage of applicants accepted by colleges represent one readily available, though not completely reliable indicator of increased selectivity. Table 2 displays how the percentage of students accepted has changed from 1986 to 2003 using data from the American Survey of Colleges (ASC), which contains detailed information on institutional classification, enrollment, applications, student body profiles, and expenditures. The results are broken down by sector and by the ranking of the institution. ${ }^{1}$

Three patterns are clear from Table 2. First, all categories—indeed, all individual schools in the sample-reduced the percentage of applicants they accepted during the period. Second, the most dramatic changes occurred among the more highly-ranked institutions; for example, the top 20 private and top 20 public universities both saw the percentage of applicants accepted fall by about a quarter over this time. Third, in terms of timing, the most dramatic reductions in the percentage accepted happened late in this time period, at about the same time cohort size began to grow.

Trends in college selectivity also differed by region. In 1986, four-year institutions in New England and the Middle Atlantic states accepted the smallest percentage of applicants in comparison to other regions (67.5 and 69.3 percent, respectively). By 2003, they remained the regions with the lowest acceptance rates: only about 64 percent of applicants were accepted on average at institutions in these regions. To some extent, this reflects differences in the mix of colleges across regions, with many of the most selective schools located in the Northeast. But the declines in acceptance rates within region and public/private status are still notable. During the period, the average percentage

\footnotetext{
${ }^{1}$ See the Data Appendix for details on the ASC dataset and institutional rankings, including a list of the schools. The bottom row reflects the number of institutions represented by the data. As reflected in the numbers, the ASC is
} 
accepted by private four-year institutions in New England fell 9 percent (from 64.8 to 59.0 percent), while in the Middle Atlantic States, most of the decline happened among public four-year institutions (from 64.3 to 55.7 percent, or a 13.5 percent change). The West also became much more competitive during the last several decades as only 68.9 percent of applicants were accepted by institutions within the region in 2003 (a 5.2 percent change from 1986).

These trends highlight that competitiveness in higher education has become particularly heightened in the northeastern United States and in California. The South, Midwest, and Southwest also experienced reductions in the percentage of students accepted by four-year colleges and universities during this time, but even in 2003, more than seven out of ten students were accepted on average at institutions within their borders. The most notable changes during the time period occurred in the Southwest for both public and private institutions (a 12.4 percent decline to 74.3 percent being accepted in 2003), among public institutions in the South (a 9.4 percent decline to 66.4 percent in 2003), and within private institutions in the Midwest (a 8.7 percent decline to 74.1 percent in 2003). Since most college-going students still attend a college in their home region, these numbers suggest that the difficulty of getting into college for a typical applicant varies geographically.

The ACS also reports information on the distribution of college entrance exam test scores for entering classes. These data show quite clearly that incoming students have higher scores on college entrance exams than they used to. Figure 1 displays trends in the $75^{\text {th }}$ percentile math SAT score of schools' student bodies; the results are broken down by institutional sector and ranking. Again, all schools in the sample experienced increases in student body test scores at the $75^{\text {th }}$ percentile, but the largest changes occurred among the top ranked schools. The growth from 1986 to 2003 was particularly large among public universities in the top 20 (52 points on the SAT, or an 8.1 percent change). Among the private institutions, the top 20 universities and liberal arts colleges experienced of "Other Public Four-years" includes public colleges (as opposed to only universities). 
an average increase of 41 points to 749 , a score much higher than that found at other schools. The trends for math SAT scores are similar to those also found for verbal SAT scores and for the ACT. ${ }^{2}$

\section{Student-Level Indicators of College Acceptance}

A caveat about the institutional-level acceptance rates above is that the composition of applicants, as well as the number of applications per student, may be changing, and so a lower share of acceptances may only be partially revealing about increased selectivity. Thus it also important to look at the student perspective, and another measure of selectivity is whether students are able to attend their first-choice college. According to data from surveys of college freshmen done by the Cooperative Institutional Research Program (CIRP) at the University of California, Los Angeles's Higher Education Research Institute (HERI), about 22 percent of students report that they were not able to attend their first choice for college in 1974, while 33 percent reported in 2006 that they were not able to do so. This result is not surprising given, as pointed out in the introduction, the availability of slots has remained relatively fixed or increased very slowly, particularly at the most highly-ranked schools.

More detail is available by analyzing data from the National Center of Education Statistics (NCES), which allow us to track application behavior and acceptances over time by student background. The results are weighted to be nationally representative. Four longitudinal surveys from the NCES provide data on secondary students who would have graduated high school in 1972 (the National Longitudinal Study of the High School Class of 1972 or NLS72), 1982 (the High School and Beyond or HSB82), 1992 (the National Educational Longitudinal Survey or NELS92), and 2004 (the Educational Longitudinal Survey or ELS04). Table 3 displays the percentage of students who

\footnotetext{
${ }^{2}$ If anything, these measures understate the increased selectivity of top ranked schools. Given that the number of highly qualified students applying to selective colleges has increased dramatically over the last few decades, the odds that an applicant in the top quartile of selective colleges test score distributions is admitted has declined. McDuff (2007) calculates that, as of the 1990s, less than 40 percent of applicants to Princeton with SAT scores in the top 25 percent of the Princeton college class actually end up attending Princeton.
} 
applied to a four-year institution by cohort and sector. ${ }^{3}$ Reading across the cohorts, it is clear that the percentage of students applying to a four-year institution has increased over time, from 29 percent among the 1972 high school graduates to 53 percent in 2004. The percentage applying to selective public institutions has also grown to 12.8 percent for the high school class of 2004. A smaller share of students apply to selective private four-year schools (6.2 percent in 2004), and recently there has been a small decline in the percentage (from 6.7 percent in 1992). Given the falling institutional-level acceptance rates seen in Table 2, it is worth noting that this decline would have been even greater had the application rate at selective privates held steady or even risen.

Not surprisingly, higher ability students were more likely to apply to selective institutions, with 20.4 and 30.1 percent of the fifth, or top, quintile of the 2004 graduating class applying to a selective private or public institution, respectively. However, Table 3 also emphasizes increasing proportions of students at all ability levels applying to four-year institutions, including selective schools. This has affected the overall ability composition of applicants to different types of colleges over time. As Bound, Lovenheim, and Turner $(2007,2008)$ have documented, the average quality of applicants to four-year colleges declined between 1972 and 2004, with most of the decline concentrated between 1982 and 1992. Using aggregate numbers available from the Department of Education and our calculations based on NCES longitudinal student surveys, we compare how the number of applicants from each ability quintile has changed over time at different types of schools. The share of applicants from the top two quintiles of the ability distribution, for instance, fell from 69.4 percent in 1972, to 67.5 percent in 1982, 60.0 percent in 1992, and 57.7 percent in 2004. Stated another way, 750,000 more students applied to a four-year college in 2004 than in 1972, and half of these came from the third and fourth ability quintiles. The average applicant quality also declined at selective private and public schools. The share of applicants to selective private schools from the top ability quintile fell from 71 percent in 1982 to 66 percent by 2004; for applicants to public selective publics, the equivalent share has fell from 53 percent to 47 percent. Declining cohort sizes forced

\footnotetext{
${ }^{3}$ The numbers in Table 3 do not accord perfectly with those in Table 1 because the latter are conditional on the respondent having graduated from high school, whereas the numbers in Table 3 are conditional on the respondent being a senior in high school. The basic trends between the two tables, however, are the same.
} 
colleges to accept more students from lower in the ability distribution in 1992, but with the rapid rise in cohort size over the next decade, schools were able to be much more selective by the early 2000s, as observed in Table 2.

The propensity to apply to a four-year institution, particularly a selective one, also differed by region. Students from New England were by far the most likely to apply to a selective private school, although this proportion dropped from 19.4 percent in 1992 to 14.4 percent in 2004 . Students from the Middle Atlantic States are the second most likely, and this region shows a drop-off similar to New England. At the selective public four-years, students from the Midwest are the most active, followed closely by students in the South and New England. Notably, students in the West increasingly applied to both selective publics and privates, with the proportion increasing throughout the 32-year period.

These changes in application rates over time and by ability and region make analysis of acceptance rates difficult. Ideally, we would like to observe how the same student who applied to college in 1972 or 1982 would fare if she applied in 1992 or 2004, instead. Because this is not possible, we instead construct a counterfactual acceptance rate that controls for the changes in applicants by ability and region that we observe in Table 3. These acceptance rates, shown in Table 4, are fitted probabilities from logistic regressions that use the 1972 high school graduating class as the baseline but allow coefficients to be survey-wave specific. Each number thus represents the mean conditional probability that a student from 1972 in a given cell would have been admitted to a given college type during the respective survey year. Generally speaking, the likelihood of being accepted by a four-year college has declined. While acceptance rates increased slightly from 1972 to 1982, this trend was reversed thereafter. From 1972 to 2004, the likelihood fell nearly 9 percent. ${ }^{4}$ The sharpest reductions occurred for low ability students. Those among the first and second quintiles saw the likelihood of being accepted by a four-year institution fall by 42.5 and 23.3 percent, respectively.

\footnotetext{
${ }^{4}$ The assertion that students with a given level of qualifications have had a tougher time getting into college is confirmed by more detailed regression analysis that controls for many additional covariates. This is presented in Appendix Table 3.
} 
Taking a broad perspective across the entire horizon of 1972 to 2004, the counterfactual conditional acceptance rate at selective private schools fell by 22.5 percent, more than twice the decline at selective publics (10.7 percent) or at the typical four-year school (8.8 percent). Among students in the highest test quintile, the reduction in the likelihood of being accepted was relatively small at selective publics and the average four-year school (4.8 and 4.0 percent, respectively) but not at the selective privates (17.0 percent). Other studies also emphasize this point. For example, McDuff (2007) finds evidence that someone with a combined SAT score of 1500 would have less than a 50 percent chance of getting into a very selective college. Students of median ability (i.e., the third quintile) also experienced a substantial decline in the likelihood of being accepted by a private selective institution (a 47.8 percent reduction). The pattern of declining acceptances at selective private institutions also holds looking across regions. While most of the regions experience a decline of roughly similar magnitude (except for the Midwest), it is worth noting that the greater share of students applying to selective private schools from New England and the Middle Atlantic states (Table 3) implies a greater number of students would be rejected from these regions under the counterfactual exercise. ${ }^{5}$

In light of the steep reductions in acceptance rates as shown in Table 4, particularly among selective private schools, and the findings of Hoxby (1997) regarding an increasingly national (and international) college market, we used data from the Integrated Postsecondary Education Data System (IPEDS) to examine the fraction of first-year students coming from a different region of the country than the school they attend, as well as the fraction coming from a different country entirely. (The IPEDS is an annual census of postsecondary institutions in the United States collected by the National Center of Education Statistics.) For the period between 1992 and 2004 among selective private schools, the share of first-year students from a different region than their school rose only slightly, from 47.9 percent to 49.0 percent. The fraction of international students increased even less,

\footnotetext{
5 This assumes student characteristics and behaviors do not change. In the appendix, once holding constant additional students traits, the conditional acceptance rates are much smaller for New England, the Middle Atlantic, and the Western states than the counterfactual rates shown in Table 4 in 1992 and 2004. This suggests students did have a behavioral response (i.e., their characteristics changed), which we explore in the next section.
} 
from 4.2 percent to 4.5 percent. $^{6}$ These numbers are too small for interregional and foreign students to be playing a significant role in rising college selectivity, at least over this period. ${ }^{7}$

It seems quite likely that college applicants (and their parents) from the Northeast (i.e., New England and the Middle Atlantic states) may be bearing the brunt of this increasingly competitive environment. Much of this has to do with the distribution of schools across the country, with far more selective private colleges than selective public colleges located in the Northeast. As a consequence, a typical talented student from the Northeast is more likely to apply to a selective private school than a typical talented student from, say, the Midwest. As we documented earlier, while the supply of slots has expanded only slightly at all selective schools, this growth has been greater at selective publics than selective privates. Additionally, a far greater share of students at selective private schools comes from out of state or out of region than at selective publics (49 percent versus 10.5 percent). All these reasons suggest that "high-ability" students in the Northeast are competing for fewer slots than their peers elsewhere in the country. From Table 3 we know that although the share of students from the New England and Middle Atlantic States applying to college overall has risen, the share applying from these regions to selective schools has declined since 1992, which suggests that students from this region are not finding the same level of access to selective schools as before. Thus, behaviors that result from the more competitive college admissions environment should tend to be more pronounced among families in the Northeast.

\section{STUDENT RESPONSES TO GROWING COLLEGE COMPETITION}

In light of the increasing difficulty of getting into a selective institution, stories abound concerning the pressure that students face to take on activities that will impress university and college admission officers. For example, Williams (2006) reported in the New York Times: “Once, summer for teenagers meant a season of menial jobs and lazy days at the local pool. But for a small

\footnotetext{
${ }^{6}$ Only at the most selective schools (the Ivy League and MIT) did the international share rise notably, from 5.6 percent to 8.2 percent, but this translates to very few slots (about 380).
} 
but growing number of college-bound students ... summer has become a time of résumé-building academic work and all-consuming, often exotic projects to change the world... There is a growing sense among college-bound seniors and their parents that downtime is wasted time, said Stacy Harvey, the college counselor at Santa Monica High School in California.”

In what follows, we evaluate the available quantitative evidence to examine whether this story is indicative of student responses to growing competition. As the return to attending and graduating from a more selective school increased while entry into such schools became more competitive, one would expect to see students invest more heavily in behaviors that would increase their chances of acceptance. Such investments could include better academic preparation, such as taking more challenging courses or being more involved in activities looked upon fondly by admissions committees. It could also include investing in signals of ability, such as focusing on improving college examination test scores. Changes in application behavior, such as the number of applications submitted or where test scores are sent, might also increase the likelihood of being accepted into a top school. Because the increase in selectivity has varied both across different ability levels of students and regions of the country, one might expect to see changes in student behavior also vary by student test score and geography. We note, however, that we cannot impart a causal interpretation to the change in student behavior, as we are unable to separate the effects of other, secular changes that are unrelated with growing competition. ${ }^{8}$ The results presented here should thus be viewed as suggestive.

\section{Academic Preparation and High School Activities}

Students have had increasing incentive to improve their academic preparation. Table 5 reports three indicators of college-preparatory high school behavior — taking calculus, taking an AP exam, and time spent on homework. Although not all indicators are available for each cohort, they

\footnotetext{
${ }^{7}$ Hoxby finds convincing evidence of increased college integration over a longer horizon; from our data, it would appear that much of the integration occurred before 1992.

${ }^{8}$ For example, the release of the seminal report A Nation at Risk in 1983 almost certainly led to major curricular changes at the high school level that had little to do with already tightening college admission standards (Peabody
} 
are measured consistently when available. The tabulations are done to represent the national average of all high school seniors at that time, as well as separately by test battery quintile, geography, and (non-exclusive) college application status.

Overall, high school students in 2004 engaged in significantly more behavior associated with college preparation, on average, than did their counterparts from 10 and 20 years before. The share taking at least a semester of calculus in high school rose from 9.2 percent to 15.2 percent between 1982 and 2004. In just the 12 years from 1992 to 2004, the fraction of seniors having taken at least one Advanced Placement (AP) exam nearly doubled, from 16.5 to 30.9 percent. Finally, while one in 20 high school seniors spent 10 or more hours on homework per week in 1972, this ratio had reached one in four by 1992. However, the share with at least 10 hours of homework did drop off from 1992 to 2004.

The recent fall in homework time is somewhat mystifying as theory predicts that, at least to the extent that homework time is positively correlated with college acceptance, homework time should increase as competition intensifies. ${ }^{9}$ Yet the trend appears otherwise. CIRP data from The American Freshman annual survey finds a similar pattern. In that data, ,the percentage of college freshmen who reported spending six or more hours per week on homework during their senior year of high school declined between the early 1990s and 2004. In their data it appears that the drop in homework time was well underway by the late 1980s, more or less continuing to the present day. The sharp rise in the percentage spending more than 10 hours a week on homework between the 1982 and 1992 NCES cohorts thus likely masks an even more dramatic spike that occurred in the mid 1980s. ${ }^{10}$

As seen by the example of homework time, this overview of trends in academic preparation can hide subtleties in the timing of the changes, particularly with regard to certain groups of students.

Journal of Education, 2004). However, it may have affected college demand if it increased the number of students prepared for higher education.

${ }^{9}$ In fact, in our own exploratory work we have found that the partial correlation between homework time and conditional college acceptance is stronger in 2004 than in 1992, whether it is for any four-year college or the selective privates or selective publics.

${ }^{10}$ We suspect this spike is due in large part to curricular reform brought about by the release of the A Nation At Risk report in 1983. Unfortunately, data limitations do not allow us to test our suspicion, but it would be a worthy topic for future research. It may also be the case that changes in the availability of alternative activities, such as online 
Separating the analysis by test quintile shows that the increases in college-preparatory behavior are widespread throughout the ability distribution. This pattern may reflect that much of the rise in anticipated college-going over the past 30 years stems from higher college application rates from those in the lower quintiles (as shown earlier in Table 3). Nonetheless, looking strictly at the changes between 1992 and 2004, when increasing competition was the most evident, the top ability quintile shows consistently the most positive movement across each of the behavior measures. This finding is largely corroborated by students applying to selective four-year private institutions, who overwhelmingly come from the top ability quintile. Between 1992 and 2004, the decline in homework time is smaller and the growth in calculus-taking is larger for students applying to selective private institutions than those applying to baccalaureate institutions more generally.

Examining the time trends by region shows that New England and the Middle Atlantic States, and to a somewhat lesser extent the West (especially California), tend to be early leaders among the college preparatory measures, but that the remaining regions tend to exhibit faster growth, if not entire convergence, over time. For instance, although the time spent on homework is fairly uniform across the country in 1972, ten years later, the Northeast and the West have clearly broken away from the rest of the country.

Other data provide further support of a trend toward increasing academic preparation. Data from the College Board gives a more detailed account of the growth of the AP program. Begun at a few pilot secondary schools in the mid 1950s as a way for superior students to earn college credit while still in high school, by 2007 some 1.4 million students at over 13,000 high schools throughout the country took 2.5 million exams in over 30 subjects. On a per-capita basis, fewer than 2 out of a 100 18-year-olds took an AP exam in 1977; 30 years later, this ratio had reached 34 out of a 100. While the growth has been remarkably stable—since 1970, both the number of takers and the number of exams have increased at roughly 10 percent per year-it has not been even throughout the nation.

Administrative data from the College Board, which is shown in Figure 2, suggest that AP program participation was relatively rare from the 1970s into the early 1980s: among the early 
leaders of New England, the Middle States, and the West (mostly California), the participation rate was roughly 5 percent, while in the South, Southwest, and Midwest, it was scarcely half that. Over the next 25 years, while all regions exhibited rapid growth, the South and Southwest experienced a meteoric rise, particularly since 1998, allowing them to converge with the early leaders, and in the case of the Southwest, surpass them. As of 2007, only the AP participation rate in the Midwest, a region that has not shown particularly sharp increases in competitive pressure, noticeably lags the other regions. This pattern is also illustrated using the NCES data by the middle columns of Table 5.

Of course, the AP program has at two main purposes: it allows for earning college credit while still in high school, reducing the costs of college attendance, and it can also serve as a signal of academic ability to prospective colleges. As college costs and competitive pressures have risen, both reasons are likely to have grown more compelling. Additionally, the rising importance of signaling through taking AP exams can be seen by looking at the correlation in the change in participation rates and the change in passing rates. Each AP exam is scored on a 1 through 5 scale; scores of 3 or higher are considered "passing” and are the minimum that most colleges require for credit. Using state-level data for the period 1996 through 2007, this correlation is strong and negative; the point estimate from the regression implies that a 10 percent increase in the participation rate is associated with a 2.6 percentage point decline in the pass rate. This finding is consistent with much of the recent growth in participation coming from marginal students who would not have taken an AP exam in the past but have an increased desire to signal ability.

Involvement in extracurricular activities may also affect chances for college admission. As displayed in Figure 3, data from CIRP's Freshman Survey shows that the percentage of college freshmen who regularly volunteered during their senior year of high school increased rapidly from about 45 percent in 1987 and 1988 up to about 70 percent by 2000, where it has roughly remained since. Similar increases are reported across institutions of different selectivity, although those at highly selective institutions consistently report volunteering at higher rates (77 percent in 2004) than do those at institutions of medium or low selectivity (72 percent and 68 percent, respectively, in

needed to explore this hypothesis. 
2004). However, other data suggest that participation in school clubs has decreased in recent years. The percentage of students reporting having spent at least six hours per week in a school club fell from 18 percent in the early 1990s to about 14 percent by the mid 2000s. Interestingly, the drop off is most pronounced among students attending the most selective colleges. This result, like the homework results, deserves further investigation to better understand how time use among students has changed in recent years.

Taking this evidence together, we find mixed evidence in support of the hypothesis that high school students are undertaking rational behavioral responses to increased college selectivity. Over the entire period from the early 1970s through the early 2000s, high school seniors increased the time spent on homework and became more likely to take advanced classes like calculus and AP exams. Furthermore, the parts of the country that we identified in the preceding section as having experienced the earliest and most pronounced growth in college admission competition—primarily New England and the Middle States-also exhibited earlier and more significant growth in homework time and calculus course-taking. The same pattern holds for students applying to selective private schools, and, to a lesser extent, those at the top of the ability distribution. Within the last 15 years, when competitive pressures were growing the most quickly, AP exam taking and time spent volunteering rose. However, this growth was stronger in the parts of the country outside the Northeast, for students below the top ability quintile, and for those not applying to private selective schools - in other words, the segment of the student population that experienced lesser increases in college competition. Moreover, time spent on homework and on extracurricular and leadership positions actually declined in this period. Perhaps students have substituted some of their time away from homework and extracurriculars and toward AP exams and volunteer time. The magnitude of how different factors affect college admissions for students in different positions, and whether such substitution makes sense, remains to be investigated.

\section{Standardized Test-taking and Test Preparation}


The share of high school seniors taking either or both the primary college entrance examinations, the SAT and the ACT, has risen in recent decades. The SAT, or the Scholastic Aptitude Test, is the older examination and is more popular on the east and west coasts. The rival ACT is broader in its coverage of material, more popular in the middle of the country, and has grown in popularity in the last 25 years.

The first set of columns of Table 6 show the fraction of high school seniors, by cohort, that took either of these college entrance examinations. While this proportion has increased moderately from 56.1 to 64.6 percent between 1982 and 2004, this increase has not been uniform. As has been documented earlier, much of the growth has come from marginal students lower in the ability distribution, with the concomitant slowdown being driven by the plateau among the higher ability quintiles. In fact, the share of students applying to selective schools or coming from the competitive New England and Middle Atlantic regions who took a college entrance exam actually declined from 1992 to 2004. This counterintuitive trend may in part be a backlash against the stress associated with increased competition: many colleges and universities, including several selective ones no longer require either test for admission (Bruno, 2006). ${ }^{11}$

Of course, the numbers in Table 6 may mask differences between the SAT and ACT. Students in both New England and the Middle Atlantic States use the SAT more heavily; nearly three out of five 18-year-olds have taken the test in these regions in recent years, nearly twice the rate of the rest of the country, based on our tabulations of the NCES surveys. Nonetheless, every region of the country except for the Midwest, where the ACT is most prevalent, has shown a sizable increase in the SAT-taking rate over the past 35 years, with this increase accelerating within the past 10 years. The fastest growth has come from the Southwest and West regions, where participation rates have increased nearly 75 percent since 1972, and over 20 percent just since 1997.

Considering that most colleges require at least one of the entrance examinations but generally accept either, it is useful to look at patterns of students taking both the SAT and ACT. In some cases,

\footnotetext{
${ }^{11}$ For a nice treatment of the selection and signaling decisions of students under a test-optional policy at a selective college, see Robinson and Monks (2004). Fairtest, an organization critical of standardized testing, maintains a list of "SAT/ACT-optional" schools on its website at <http://www.fairtest.org/university/optional>.
} 
students perform better on one than on the other, and the mitigation of risk from taking both tests may exceed the financial and psychic costs. Using the NCES panels to construct snapshots of combined test-taking, about one in eight college-bound seniors took both tests in 1972, and by 2004 this ratio had increased to one in five. Among those applying to private, selective schools, however, both the levels and rate of increase are greater: about 15 percent of these students took both in 1972, and 35 percent took both by 2004. Unfortunately, the NCES data are not able to pinpoint the timing of this increase precisely. Examining aggregate ACT participation rates in predominantly SAT states, ${ }^{12}$ although a crude proxy, provides higher frequency data. In just the six years between 2001 and 2007, the New England and Middle Atlantic regions have seen their ACT participation rates nearly double, from about 6 percent to 11 percent. As SAT participation rates have also increased during this period, it seems plausible that the rate of combined test-taking in these areas has increased considerably in recent years.

With the growing importance of the SAT and ACT in admissions, students have had increasing incentive to invest in test preparation services. Table 6 also displays trends in private classes or tutoring and any form of test preparation for the 1992 and 2004 cohorts. Using some kind of test preparation service is more common among those who are higher ability and those who applied to a four-year institution, particularly a selective private school. Within each type of preparation, there has been an increase in the percentage of students reporting formal help. The increases in test preparation are most pronounced for higher ability students. ${ }^{13}$ The large increase in the South mirrors the rise discussed earlier in the region's SAT/ACT participation and in other preparatory measures.

Retaking the test is another way in which students may respond to competitive pressure. According to a College Board report, of the 1.1 million students of the class of 1997 who took the SAT, just under half took the test more than once (Camara and Nathan, 1998). Vigdor and Clotfelter (2003), using a special sample of complete SAT score reports for the applicants to three private,

\footnotetext{
${ }^{12}$ This set of states is quite consistent over time. See the Data Appendix for a list.
} 
selective schools in the South, find that the policy at many colleges to look at only the highest submitted score provides powerful incentives for test retaking, and this policy disadvantages those with high costs of test-taking. We suspect that retaking of the SAT, as well as the ACT, for which there is even less data, has risen considerably in recent years, but without better data we are unable to test our hypothesis.

Finally, some students (or their parents) might seek an advantage by obtaining special accommodations during the test, such as additional time or a less-crowded room. ${ }^{14}$ Abrams (2005) provides suggestive but compelling evidence that the College Board's decision in 2003 to end “flagging” of tests given under non-standard conditions resulted in benefitting the savvy and well-todo, with unprecedented score gains for non-standard-condition test takers in Washington D.C. and wealthy communities in California. We extend Abrams' analysis slightly by examining the fraction of SAT takers under non-standard conditions in selected (SAT) states in 2003 and 2004, the years bracketing the policy change. In states where the SAT is prevalent and competitive pressures have risen sharply - New York, Massachusetts, Connecticut, New Hampshire, New Jersey, and Maryland — the share of those taking the SAT under nonstandard conditions ranged from 3.4 to 5.2 percent. In a selection of five states six states where the SAT is also prevalent but competitive pressures have risen less - Indiana, South Carolina, North Carolina, Georgia, and Oregon — the share of those taking the SAT under nonstandard conditions ranged from 0.8 to 2.4 percent.

\section{College Application and Score-Sending Behavior}

Applying to a different or larger set of schools may feel to many students and their parents like a relatively easy and inexpensive way to increase the chance of college acceptance. In the mid1970s, the Common Application began as a near-unified college application form among a consortium of selective, private schools. Membership in the consortium has grown considerably

\footnotetext{
${ }^{13}$ Non-response to the test preparation questions in the 2004 survey is high (approximately 25 percent) and is strongly negatively correlated with socioeconomic status (income or parental education). The inference should thus be treated cautiously.
} 
since then: by 2007, nearly 300 institutions participated. Moreover, Internet-based applications began in 1998, and public institutions were invited to join in $2001 .^{15}$ These innovations, which obviate having to write multiple essays and fill out multiple forms by hand, have almost certainly reduced the cost of applying to a wider variety and greater number of colleges even further.

Figure 4 investigates the trend in the number of college applications with data drawn from the CIRP Freshman Survey. Like the earlier Freshman Survey figure, the series exist for successful matriculants at baccalaureate-granting institutions from the late 1960s through 2006, as well by institutional selectivity for selected years. While 25 percent of students had applied to four or more schools in 1972, more than half had by 2004. Figure 4 shows that the percentage of students applying to seven or more schools rose from about 3 percent in 1972 to 18 percent in 2004. This implies that more than half of the increase among those applying to four or more schools is driven by those applying to seven or more schools; within the last ten years, more than three quarters of the increase is from those applying to seven or more schools. The increase in application rates has been widespread throughout the selectivity distribution, with students at highly selective institutions not only sending more applications on average, but also increasing the number of applications sent at a faster pace earlier on.

Another proxy for college application behavior is the number of SAT score reports sent to various colleges. ${ }^{16}$ When taking the SAT, students are allowed to send up to four score reports at no additional marginal cost. However, in recent years, students have been sending far more score reports. As shown in the three panels of Figure 5, the number of scores sent (and the likelihood of sending more than four) rises dramatically with the student's score. For those with scores above 1400 (around the $97^{\text {th }}$ percentile), the median number of reports sent is around eight, which suggests that even students with very high scores do not feel that they can rely on being accepted into a top school.

\footnotetext{
${ }^{14}$ Non-standard conditions may include (i) presentation enhancement (large print/audio-magnification of materials), ii) alternative response (e.g., via a tape recorder instead of pencil, (iii) extended time, or (iv) alternative setting (e.g., private room).

${ }^{15}$ For more information, including a complete membership list, see <http://www.commonapp.org>.

${ }^{16}$ This is true for ACT reports, as well. We use SAT score reports here because they have a much higher topcode on the number of scores sent (15) than do the corresponding ACT data (six), allowing a finer and more detailed analysis.
} 
Table 7 illustrates how the number of reports sent varies with score. About three out of 10 students with barely above-average SAT scores, in the 1000 to 1090 range, send six or more score reports; 1 out of 8 in this range of test scores sends eight or more. Throughout the table, the fraction of students sending a given number of reports rises with the test score.

\section{HAS GREATER COMPETITION INCREASED LEARNING?}

The increasingly competitive environment in higher education has increased the level of anxiety that many high school students and their families experience (Lombardi, 2007; Kaufman, 2008). Beyond this, it is natural to wonder whether the increasingly competitive environment has made the typical high school student experience more productive. On one hand, an increasingly competitive environment could induce students to work harder at school and, as a result, to learn more during their high school years; on the other hand, certain mechanisms might lead to the opposite outcome. For example, capable students may spend time on activities that will enhance the chance they obtain admission to selective colleges at the expense of spending time on other activities that might be more productive; Holmstrom and Milgrom (1991) represent the classic formal model of this general phenomenon.

Raising the possibility that increasing competition in higher education may be counterproductive takes us into some profound and difficult questions of education policy. For example, to what extent will an increase in students taking SAT tests or AP exams increase learning? Time spent in an SAT test preparation classes, focusing on strategies for more efficient time use or guessing during the exam, may accomplish relatively little to enhance learning. In contrast, one could imagine that students do learn some history or biology while taking high school courses to prepare for the AP tests in these areas. However, the AP tests put a heavy emphasis on memorization of detailed facts because such knowledge is easier to test and to measure. Some students might learn more about softer aspects of various subjects (say, history) and about how to pursue these interests on their own if they were taking classes not focused on the AP exam. One prominent study 
commissioned by the National Science Foundation and the U.S. Department of Education concluded that AP courses crammed in too much material at the expense of understanding, and that many were taught by teachers who did not have sufficient background in the field (National Research Council, 2002). As a result of these kinds of issues, some highly prestigious private and public high schools are abandoning AP classes (Hu, 2008).

Another major question of education policy is the balance between intrinsic and extrinsic motivation. Kreps (1997) and many others have emphasized that a key value of education is to build an intrinsic motivation for learning. However, the current increasingly competitive high school environment seems to put more emphasis on the extrinsic rewards associated with study, which can result in several problems. For example, even capable students may learn less when under heavy pressure (Ariely et. al., 2008). This would be true if capable students spent a great deal of time worrying about getting into the college of their choice rather than simply focusing on their studies. At the other end of the ability spectrum, less capable students may effectively give up trying either because they know their chances of getting into a selective school are small or because they do not want to subject themselves to possible humiliation. Moreover, the experimental literature has found evidence that in certain settings extrinsic motivations and rewards can reduce the pressure of intrinsic motivation (Heyman and Ariely, 2004; Gneezy and Rustichini, 2000a, 2000b). Readers who doubt that many students are intrinsically motivated are likely to imagine increased competition causing students to work harder, while those who think that many students are internally motivated will more likely think that increased competition and external pressure will take time away from more productive activities. But many educators would express some trepidation if they believed that colleges are showing an increasing tendency to select those who are externally motivated at the expense of those that are internally motivated.

The efforts that students and their families make to increase their attractiveness to colleges also have a number of undesirable consequences for equity and efficiency. If some families are in a better position than others to invest in valuable signals, either because they are more aware of what colleges are looking for, or because they have more resources to make the appropriate investments, 
these families will have an advantage over other families, with negative consequences for both the efficiency and equity of college selection (Leonhardt, 2004). For instance, when some students take SAT prep courses and others do not, the information value of SAT scores is reduced. The high stakes (or perceived high stakes) involved in college admissions naturally leads parents at least partly to game the system. Such behavior is naturally reinforcing. If everyone else in your school is managing to figure out ways to take the SAT untimed, it would seem foolish not to do so oneself. To the extent the admission process is seen as a process that can be manipulated, students learn that the appropriate strategy to make the most of any advantage they may be able to obtain (Rabin, 1993).

Taking all the factors together, has the increased competitive environment for higher education improved the learning of high school students or has it been counterproductive? Persuasive evidence as to which view is right is exceedingly hard to come by. Various authors have found evidence that many U.S. college students are not particularly hard-working or motivated (for example, Sabot and Wakeman-Linn, 1991; Hersch and Marrow, 2005; Nathan, 2006). However, this research does not make comparisons across time, nor does it offer a way to gauge the importance of the increasingly competitive nature of college admission on the outcomes observed.

We attempt to fill this gap by comparing trends across states in outcomes that we believe are valuable metrics of social welfare. In particular, we examine four indicators: the percentage of 19year-olds enrolled in college, the percentage of 25-year-olds with at least some college, the percentage of 25-year-olds with at a bachelor's degree, and real annual labor earnings of 25-year-olds who were employed and not attending school. Using the Integrated Public-Use Microdata (IPUMS) data for the 1980 Census and the 2005-2007 American Community Surveys, we constructed statelevel averages of the above variables. The 1980 values capture high school experiences of the 1970s, well before the period of increased competitive pressure to get into college. The 2006 values, on the other hand, correspond to high school during the late 1990s and early 2000s, when we have seen pressure to be much higher.

If increased competition leads high school students to become more engaged in their studies, it seems plausible that its effects could also show up in the number of students pursuing advanced 
education. Thus, we also examine per-capita Ph.D. production. Using data from the Survey of Earned Doctorates (SED), an annual census of Ph.D.s earned in the U.S. that contains state and year of high school graduation, and limiting ourselves to those who graduated from high school in the U.S., we constructed the number of Ph.D.s awarded for each state and high school graduating class from 1972 through 1995. ${ }^{17}$ In addition to total Ph.D.s, we also generated counts for Ph.D.s earned at the top 15 research universities in the country, science and engineering Ph.D.s, and science and engineering Ph.D.s from the top 15 research universities. ${ }^{18}$

In order to compare trends across more and less competitive states, of course, one must delineate which states are in which group. At first, we constructed a binary measure of competition based on a reading of the popular press, our own intuition based on the data, and geographic simplicity. We coded as competitive states all of New England, the Middle Atlantic States (New York, New Jersey, Pennsylvania, Delaware, Maryland, and Washington, D.C.), and California. However, because this measure is ad hoc and possibly prone to error, we also created a composite index of competitive pressure for each of the 50 states plus the District of Columbia. This index is calculated as the sum of the fractions of students who engaged in each of the following behaviors in 1992: took the PSAT, took an AP exam, spent 10+ hours on homework per week, used private test preparation services, and applied to five or more colleges. Reassuringly, the top six states from this index, New Jersey, Rhode Island, D.C., Connecticut, Massachusetts, and New York, match quite closely with the ad hoc measure above (see Appendix Table 5 for the full, rank-ordered list). There appears to be a natural gap between the states ranked sixth and seventh, so we group these first six together. We then matched our competitive index to the SED and Census data (for the latter, we

\footnotetext{
${ }^{17}$ Our SED data run through 2005, but because of the significant time lag from high school graduation to PhD receipt (Hoffer and Welch, 2006), we limit the sample to those who graduated high school in or before 1995.

${ }^{18}$ Graduate programs are ranked by field, not university. However, top departments tend to be concentrated at a relatively select group of universities. Using the U.S. News and World Report rankings of graduate departments in the sciences, social sciences, and humanities, we looked for universities with many departments listed among the top ten. We found ten private universities (Cal Tech, Columbia, Cornell, Harvard, Johns Hopkins, MIT, Princeton, Stanford, University of Chicago, and Yale) and four public Universities (UC Berkeley, UCLA, UC San Diego including Scripps Institute, and U Michigan) that included many top 10 departments. During the period in questions these universities granted just under 20 percent of all Ph.D.s granted to graduates of U.S. high schools who went on to get Ph.D.s in the U.S.
} 
used an individual's state of birth as a proxy for state of high school attendance). ${ }^{19}$ For ease of interpretation, we created dummy variables for whether a state was among the six most, or eleven most, competitive. Summary statistics for all of the indicators, broken down by competitive state grouping, can be found in Appendix Table 6.

Table 8 presents estimates of the outcome variables as a function of the competitive state dummy, a linear time trend, and their interaction. In Panel A, we employed OLS on the Census measures expressed in natural logarithms. Because the Ph.D. measures in Panel B are count data, we used a Poisson model that also included a control for the natural logarithm of the state's population, the coefficient of which was constrained to be equal to $1^{20}$ For the sake of brevity, only the coefficient from the interaction term, which captures the differential time trend of the competitive states, is shown, although the full estimates are available upon request. Given the specifications used, the coefficients shown can be interpreted as the percent difference in the growth rates between the competitive and less competitive states. Each coefficient is from a separate regression, either in terms of the outcome (by columns) or in terms of the competitive state grouping (by rows). If competitive pressure has a positive effect on learning outcomes, then we would expect the interaction coefficient to be positive.

The estimates of Panel A, however, show that this is not the case; the point estimates are always negative, often statistically significantly. For example, the coefficient in the upper left shows that the fraction of 19-year-olds enrolled in college in the six most competitive states grew 0.23 percent more slowly than did this fraction for the less competitive states, and this difference is statistically significantly different from zero at the 1 percent level. Because enrollment rates were initially higher in the competitive states (see Appendix Table 6 and Figures 6a-6d) the results show that over the quarter century between 1980 and 2006, the gap between the competitive states and less competitive states in the share of 19-year-olds attending college has narrowed substantially. This

\footnotetext{
${ }^{19}$ According to the NLSY79, about 78 percent of respondents who graduated high school did so in their state of birth. However, by age 25, only 64 percent of high school graduates were living in the same state from which they graduated.

${ }^{20}$ Relaxing this constraint has virtually no effect on results. We chose to report the results that impose this constraint because these specifications are closer in spirit to the "rate" regressions in panel A.
} 
pattern is evident for each of the education measures as well as real earnings (adjusted for current state of residence, sex, education, and the interaction of sex and education) whether we restrict our definition of competitive states to the top six or the top ten. The Ph.D. estimates in panel B evince the same story. The trend for competitive state per-capita Ph.D. production in the sciences is 0.94 percent slower than for less competitive states, and it 0.8 percent slower for Ph.D.s from top schools. The differential among science and engineering Ph.D.s is even wider.

While we stop short of inferring that competition has had negative effects on these outcomes, we find no support that it has produced positive effects. In conjunction with the psychological and informational costs associated with competitive pressure that we discuss above, these results should raise doubts that the increased competition for college admission has had a net positive effect on what and how students learn.

\section{CONCLUSION}

Higher education in the United States has changed dramatically over the past 30 to 40 years. The overall demand for a college education amongst high school graduates has grown, and this has resulted in increasingly fierce competition for admission to the more selective colleges. While, as we have seen, this increase in competition has been particularly large for students who, had they finished high school in an earlier period, would have had a reasonable chance for admission to one of the more selective colleges in the country, we have also seen that the effects of the increased competition has been quite pervasive. Even students of more average ability have been affected by the changes. In terms of regional differences, competition has grown the most in the Northeast and California, although other regions have also faced increases. The increased competition that currently exists for admission to a more selective college might have real benefits if it were to increase learning amongst high school students. However, our analysis suggests that there are reasons to be suspicious that this congenial outcome might not hold true. Moreover, the increased resources parents and students are able to use to improve their odds of admission at top colleges put low-income students at a 
disadvantage. Students who attend high schools that typically do not send their graduates to top schools as well as the children of parents who did not attend selective institutions are also at a disadvantage (Roderick, Nagaoka, and Allensworth, 2006).

Interventions to reduce the selectivity of institutions seem neither practical nor sensible. However, the difference in resources per student in private and public schools may be worth addressing. Using the same categorization of schools as is utilized here, Bound, Lovenheim and Turner (2008) estimate that typical per student expenditures are four times as large at selective private colleges and universities than they are at relatively open-access public four-year schools. Winston (2000) reports even larger differences. The resources provided to students attending elite private colleges have been increasing dramatically, while the resources provided to students attending non-flagship public colleges and universities have declined significantly (Hoxby, 1997; Bound, Lovenheim and Turner, 2008). Policies designed to reduce the gap in resources available to students attending selective private schools versus those attending relatively open-access institutions might reduce the disparities in terms of college experience between those who do and those who do not obtain admission to these schools, and thus also reduce both some of the pressure students and their families feel to obtain access to a more selective college or university. The huge gap in resources available to students at selective relative to less selective schools seems too large to be justifiable on grounds of either efficiency or equity. 


\section{REFERENCES}

Abrams, Samuel J. 2005. “Unflagged SATs.” Education Next 5(3).

Ariely, Dan, Uri Gneezy, George Loewenstein, and Nina Mazar. Forthcoming. "Large Stakes and Big Mistakes.” Review of Economic Studies.

Bound, John, Michael Lovenheim, and Sarah E. Turner. 2007. "Understanding the Decrease in College Completion Rates and the Increased Time to the Baccalaureate Degree.” Population Studies center Research Report 07-626, University of Michigan.

Bound, John, Michael F. Lovenheim, and Sarah Turner, 2008, "Why Have College Completion Rates Declined? The Effects of Changes in Students and Changes in Colleges” unpublished manuscript.

Bruno, Laura. 2006. “More universities are going SAT-optional.” USA Today. April 4.

Camara, Wayne, and Julie S. Nathan. 1998. "Score Change When Retaking the SAT I: Reasoning Test.” College Board Research Notes 5 September. 1-12. Washington, D.C. The College Board.

College Board. 2008. Trends in College Pricing. Washington, D.C. The College Board.

College Board. 2008. Trends in College Pricing. Washington, D.C. The College Board.

Courant, Paul N., Michael McPherson and Alexandra M. Resch. 2006. "The Public Role in Higher Education,” National Tax Journal, LVIV, 291-318.

Finder, Alan. 2006. "In New Twist on College Search, a First Choice, and 20 Backups.” New York Times. March 21.

Gamerman, Ellen, Juliet Chung, Sungha Park, and Candace Jackson. 2007. "How the Schools Stack Up.” Wall Street Journal. http://online.wsj.com/public/resources/documents/info-COLLEGE0711-sort.html

Gneezy, Uri, and Aldo Rustichini. 2000a. “Pay Enough or Don’t Pay at All.” Quarterly Journal of Economics 115: 791-810.

Gneezy, Uri, and Aldo Rustichini. 2000b. “A Fine is a Price.” Journal of Legal Studies 29: 1-18.

Goldin, Claudia, and Lawrence F. Katz. 2008. The Race Between Education and Technology. Cambridge: Harvard University Press.

Heckman, James, Lance Lochner, and Petra Todd. 2006. "Earnings Functions, Rates of Return and Treatment Effects: The Mincer Equation and Beyond.” In Handbook of the Economics of Education, Volume 1. Amsterdam: Elsevier.

Hersch, Richard, and John Merrow. 2005. Declining by Degrees: Higher Education at Risk. New York: Palgrave Macmillan. 
Heyman, James, and Dan Ariely. 2004. “Effort for Payment: A Tale of Two Markets.” Psychological Science 15(11) November: 787-793.

Hoffer, Thomas B., and Vincent Welch. 2006. "Time to Degree of U.S. Research Doctorate Recipients.” National Science Foundation InfoBrief 06-312. http://www.nsf.gov/statistics/infbrief/nsf06312/. Accessed 1/8/2009.

Holmstrom, Bengt, and Paul Milgrom. 1991. "Multitask Principal-Agent Analyses: Incentive Contracts, Asset Ownership and Job Design.” Journal of Law, Economics and Organization 7: 24-52.

Hoxby, Caroline M. 1997. "How the Changing Market Structure of U.S. Higher Education Explains College Tuition.” NBER Working Paper WP \# 6323.

Hoxby, Caroline M. and B. T. Long. 1998. "Explaining Rising Income and Wage Inequality among the College-Educated.” NBER Working Paper No. 6873.

Hoxby, Caroline M. 2009. “The Changing Selectivity of American Colleges.”Journal of Economic Perspectives

Hu, Winnie. 2008. "Scarsdale Adjusts to Life Without Advanced Placement Courses.” New York Times. December 6.

Kaufman, Jonathan. 2008. "High School's Worst Year? For Ambitious Teens, 11th Grade Becomes a Marathon Of Tests, Stress and Sleepless Nights.” Wall Street Journal. May 24.

Kreps, David. 1997. "Intrinsic Motivation and Extrinsic Incentives.” American Economic Review 87: 359-364.

Leonhardt, David. 2004. “As Wealthy Fill Top Colleges, Concerns Grow Over Fairness.” New York Times. April 22.

Lombardi, Kate Stone. 2007. “High Anxiety of Getting Into College.” New York Times. April 8.

McDuff, DeForest. 2007. “Quality, Tuition, and Applications to In-state Public Colleges.” Economics of Education Review 26(4).

Nathan, Rebekah. 2006. My Freshman Year: What a Professor Learned by Becoming a Student. Ithaca: Cornell University Press.

National Research Council. 2002. Learning and Understanding: Improving Advanced Study of Mathematics and Science in U.S. High Schools, National Academy Press, Washington, DC.

Pryor, John, Sylvia Hurtado, Victor B Saenz, Jose Luis Santos, and William S. Korn. 2007. The American Freshman: Forty Year Trends. Los Angeles: Higher Education Research Institute, UCLA.

Rabin, Matthew. 1993. "Incorporating Fairness Into Game Theory and Economics.” American Economic Review 83: 1281-1302. 
Robinson, Michael, and James Monks. 2004. "Making SAT scores optional in selective college admissions: A case study.” Economics of Education Review 24: 393-405.

Roderick, Melissa, Jenny Nagaoka, and Elaine M. Allensworth. (2006) From High School to the Future: A first look at Chicago Public School graduates' college enrollment, college preparation, and graduation from four-year colleges. Chicago: Consortium on Chicago School Research at the University Of Chicago, Chicago Postsecondary Transition Project. Accessed June 18, 2009, from: http://ccsr.uchicago.edu/publications/Postsecondary.pdf.

Ruggles, Steven, Matthew Sobek, Trent Alexander, Catherine A. Fitch, Ronald Goeken, Patricia Kelly Hall, Miriam King, and Chad Ronnander. 2008. Integrated Public Use Microdata Series: Version 4.0 [Machine-readable database]. Minneapolis, MN: Minnesota Population Center. http://usa.ipums.org/usa/

Sabot, Richard, and John Wakeman-Linn. 1991. "Grade Inflation and Course Choice.” Journal of Economic Perspectives 5(1): 159-170.

Snyder, T.D., Dillow, S.A., and Hoffman, C.M. (2009). Digest of Education Statistics 2008 (NCES 2009-020). National Center for Education Statistics, Institute of Education Sciences, U.S. Department of Education. Washington, DC.

U.S. News and World Report. 2007. "Gold Medal Schools." U.S. News and World Report. November 29. http://www.usnews.com/articles/education/high-schools/2007/11/29/goldmedal-schools.html

Vigdor, Jacob, and Charles Clotfelter. 2003. "Retaking the SAT." Journal of Human Resources 38(1): 1-33.

Western Interstate Commission for Higher Education. 1998. Knocking at the College Door: Projections of High School Graduates by State and Race/Ethnicity, $1996-2012$ (6 ${ }^{\text {th }}$ edition).

Western Interstate Commission for Higher Education. 2008. Knocking at the College Door: Projections of High School Graduates by State and Race/Ethnicity, $1992-2022$ ( $7^{\text {th }}$ edition).

Williams, Alex. 2006. “The Lost Summer.” New York Times. June 4.

Winston, Gordon C. 1999. "Subsidies, Hierarchy and Peers: The Awkward Economics of Higher Education,” The Journal of Economics Perspectives, Vol. 13, No. 1 (Winter), pp. 13-36.

Winston, Gordon C. 2000. "Economic Stratification and Hierarchy in U.S. Colleges and Universities," Williams Project on the Economics of Higher Education http://www.williams.edu/wpehe/research.html..

Wong, Kenneth, James Guthrie, and Douglas Harris (eds). 2004. “A Nation at Risk: A 20-Year Reappraisal.” Peabody Journal of Education 79(1) (Special Issue). 
Figure 1: Math SAT $75^{\text {th }}$ Percentile by Sector and Institution Ranking

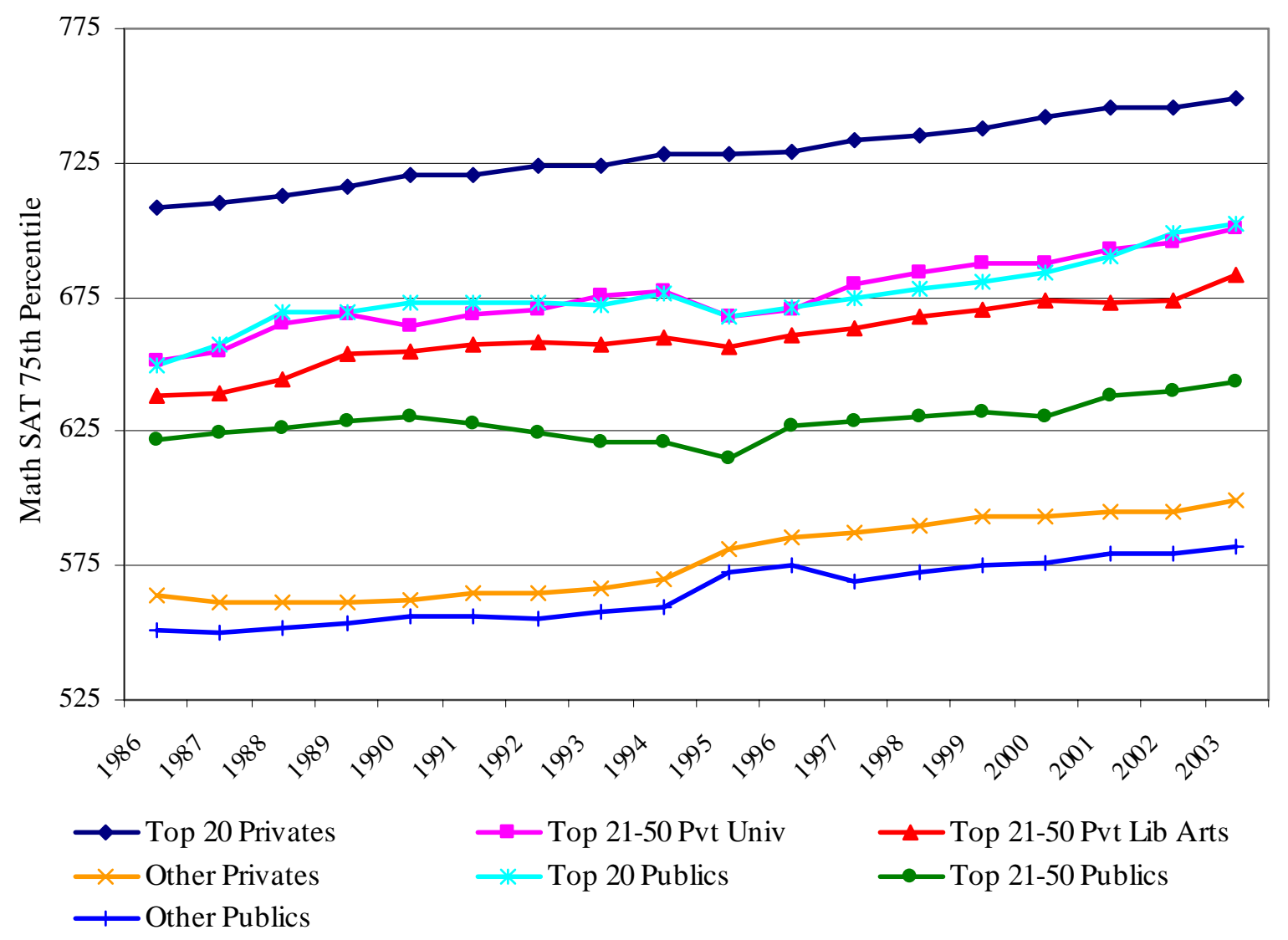

Source: American Survey of Colleges, The College Board, 1986-87 to 2003-04.

Notes: The Top 20 Private Institutions includes the top 20 private universities and top 20 liberal arts colleges. To be included in the sample, institutions must have had at least 16 of the 18 possible years of data. 
Figure 2: Advanced Placement Takers per 100 18-year-olds, By Region and Year

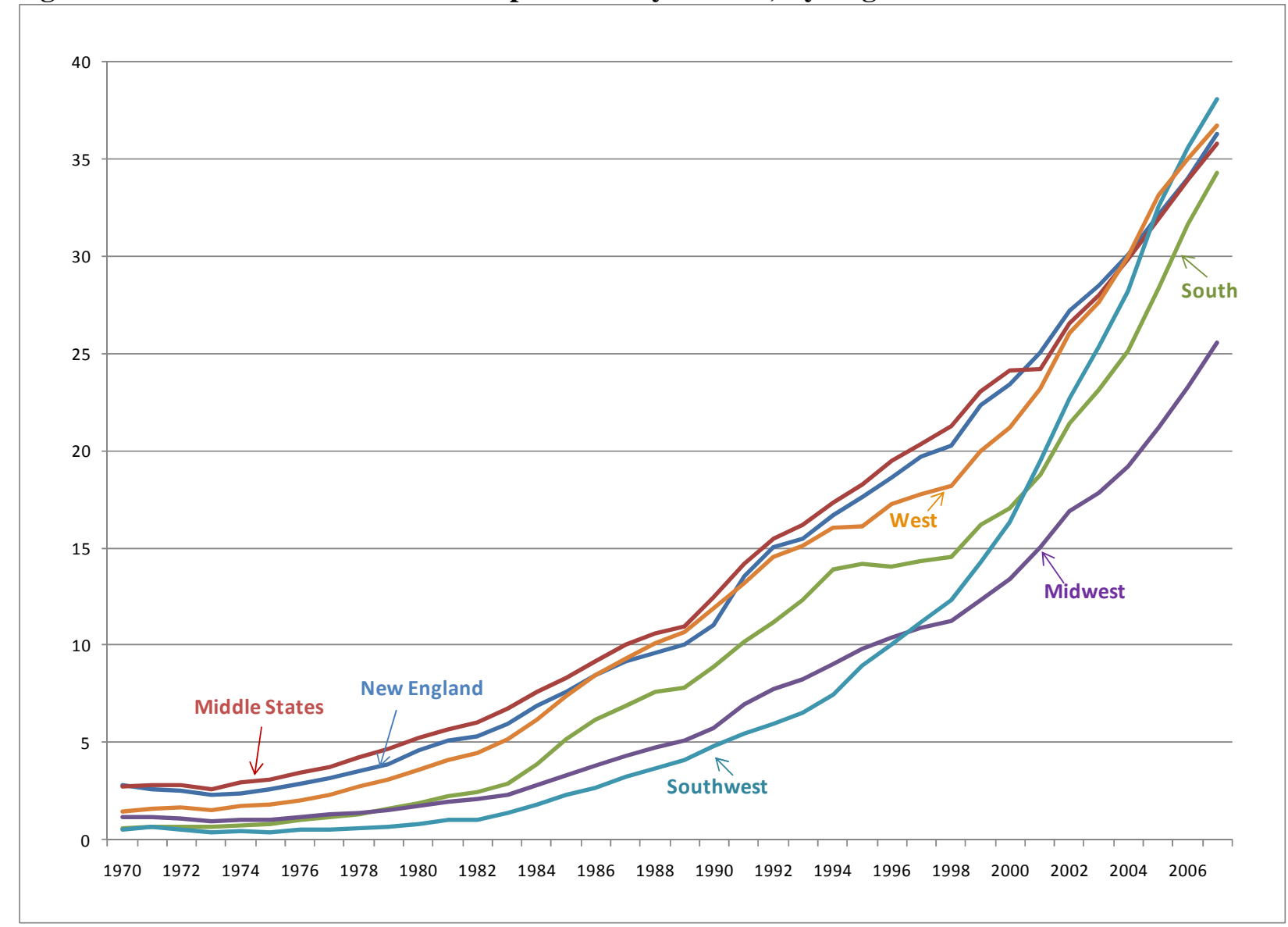

Sources: The AP data is from the College Board. The 18-year-old population data is from the National Cancer Institute.

Notes: See the Data Appendix for the regional definitions. 
Figure 3: Percentage of Students Reporting having Spent Positive Time per Week Volunteering Last Year

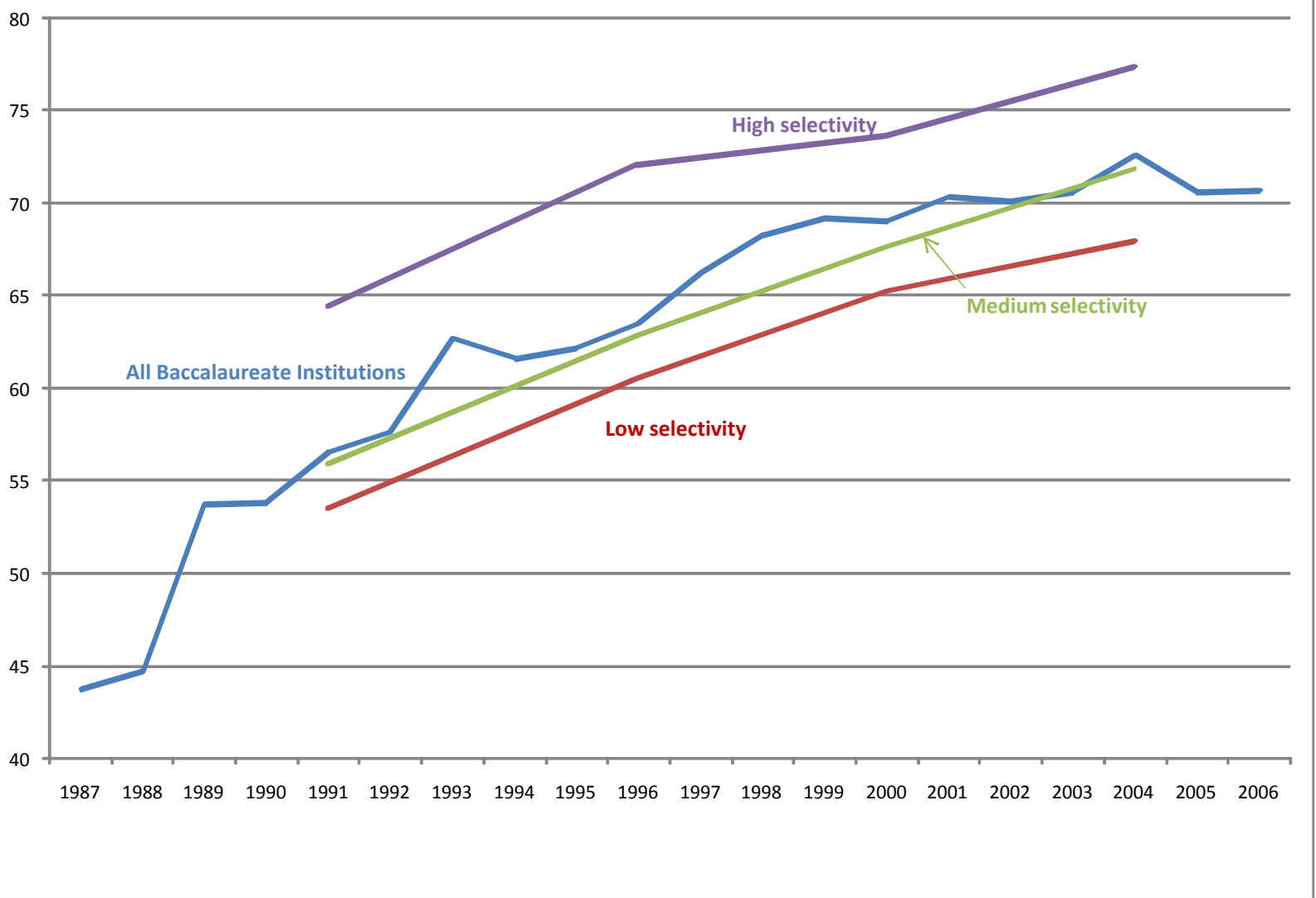

Source: The American Freshman, Cooperative Institutional Research Program (CIRP), various years.

Notes: CIRP attempts to make its sample nationally representative by stratifying participating schools by control, highest degree awarded, and selectivity, and then weighting responses to population totals from the IPEDS system. The selectivity metric used is time-varying and based on mean composite SAT score (or ACT equivalent). As a rule of thumb, high selectivity is fairly similar to our combined select private and select publics. 
Figure 4: Percentage of Students Reporting having Applied to 7+ Schools

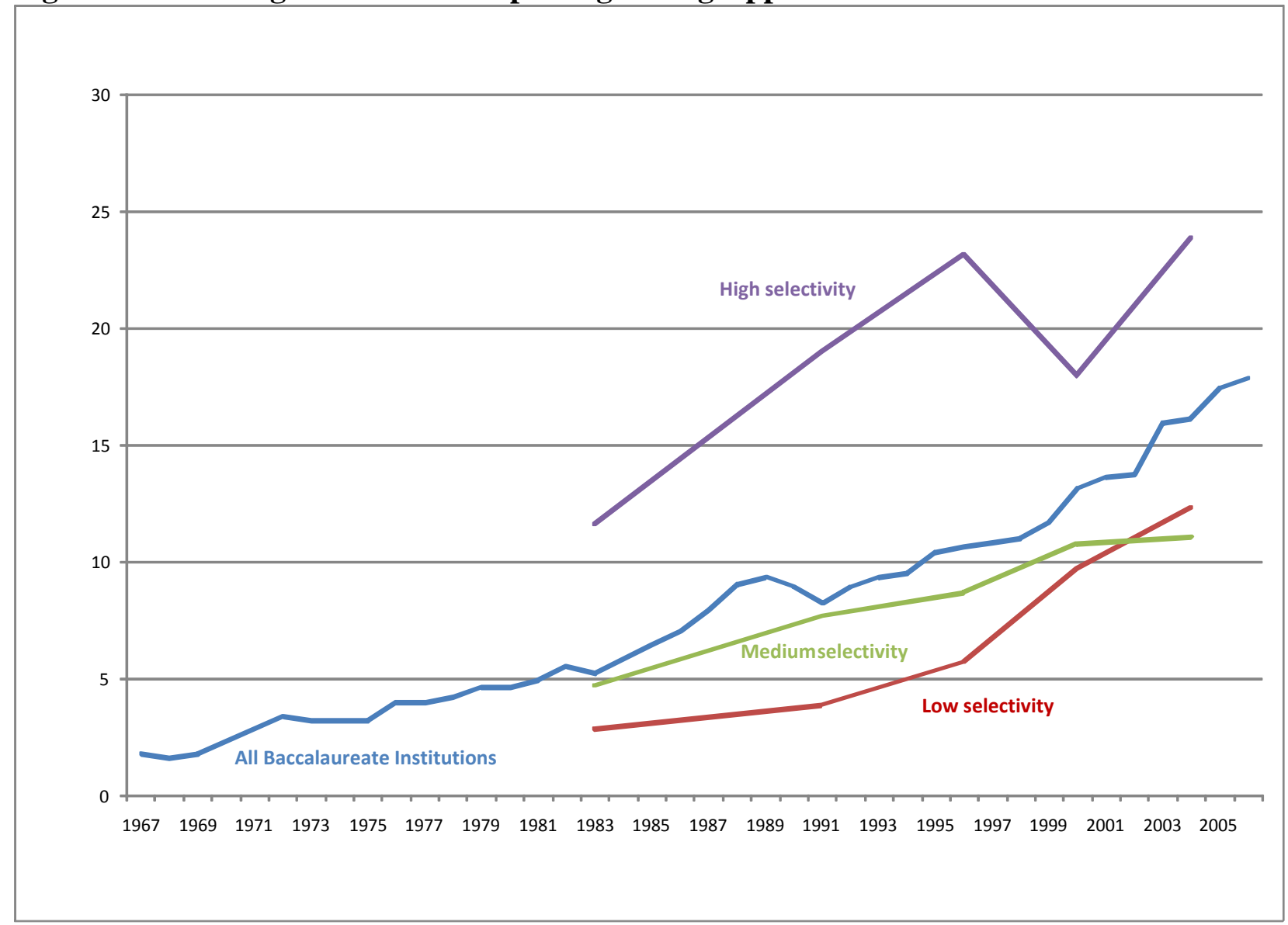

Source: The American Freshman, Cooperative Institutional Research Program (CIRP), various years.

Notes: CIRP attempts to make its sample nationally representative by stratifying participating schools by control, highest degree awarded, and selectivity, and then weighting responses to population totals from the IPEDS system. The selectivity metric used is time-varying and based on mean composite SAT score (or ACT equivalent). As a rule of thumb, high selectivity is fairly similar to our combined select private and select publics. 
Figure 5: Number of SAT Score Reports Sent, 1996-2001

\section{A. National Sample and SAT States Sample}

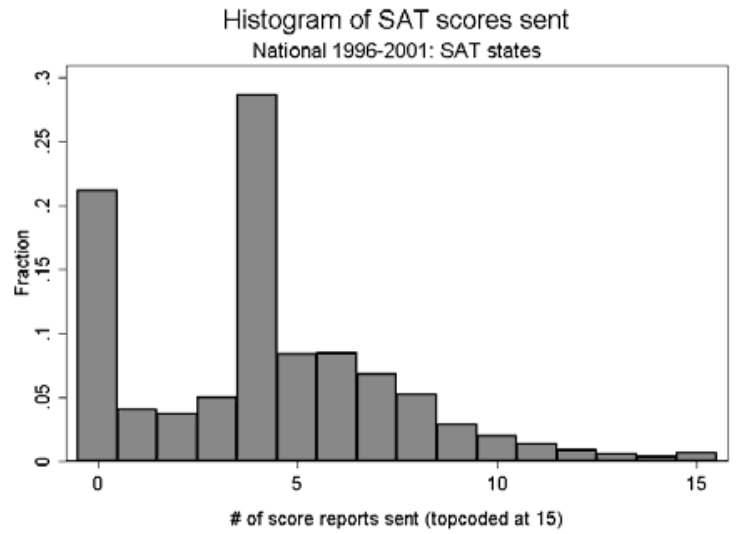

B. Students Combined SAT scores of 1200-1390

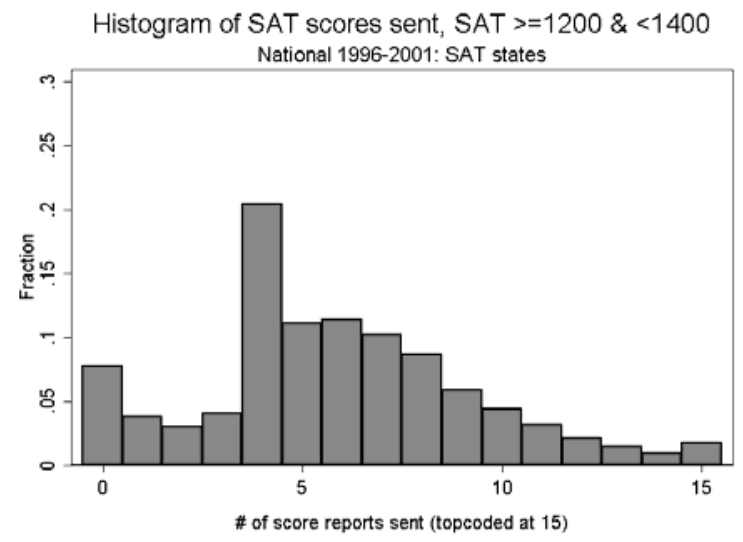

C. Students Combined SAT scores of 1400 or above

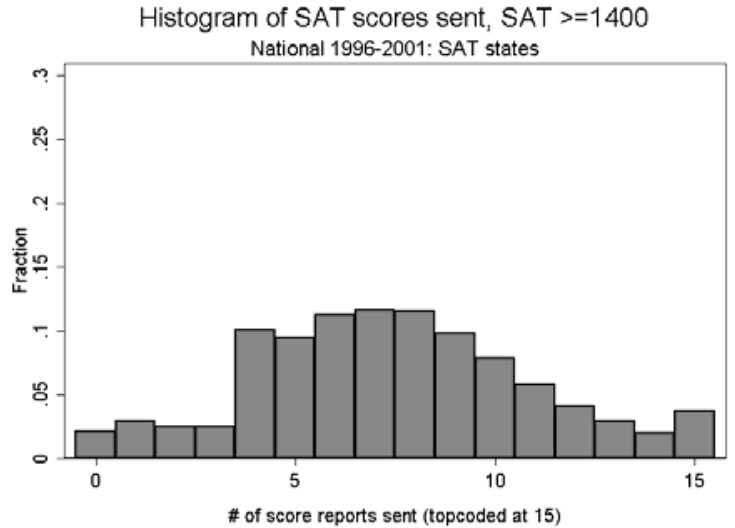

Source: The College Board (SAT data).

Notes: The SAT data cover all SAT I tests taken in the period 1996 through 2001. The test allows up to four score reports to be sent at no charge beyond the test fee. See Data Appendix for definition of SAT states. 


\section{Figure 6a: The Effects of Competition on College Enrollment}

Competitive Pressure in High School and Change in Postsecondary Enrollment, by State

Change in college enrollment of 19-year-olds between 1980 and 2006

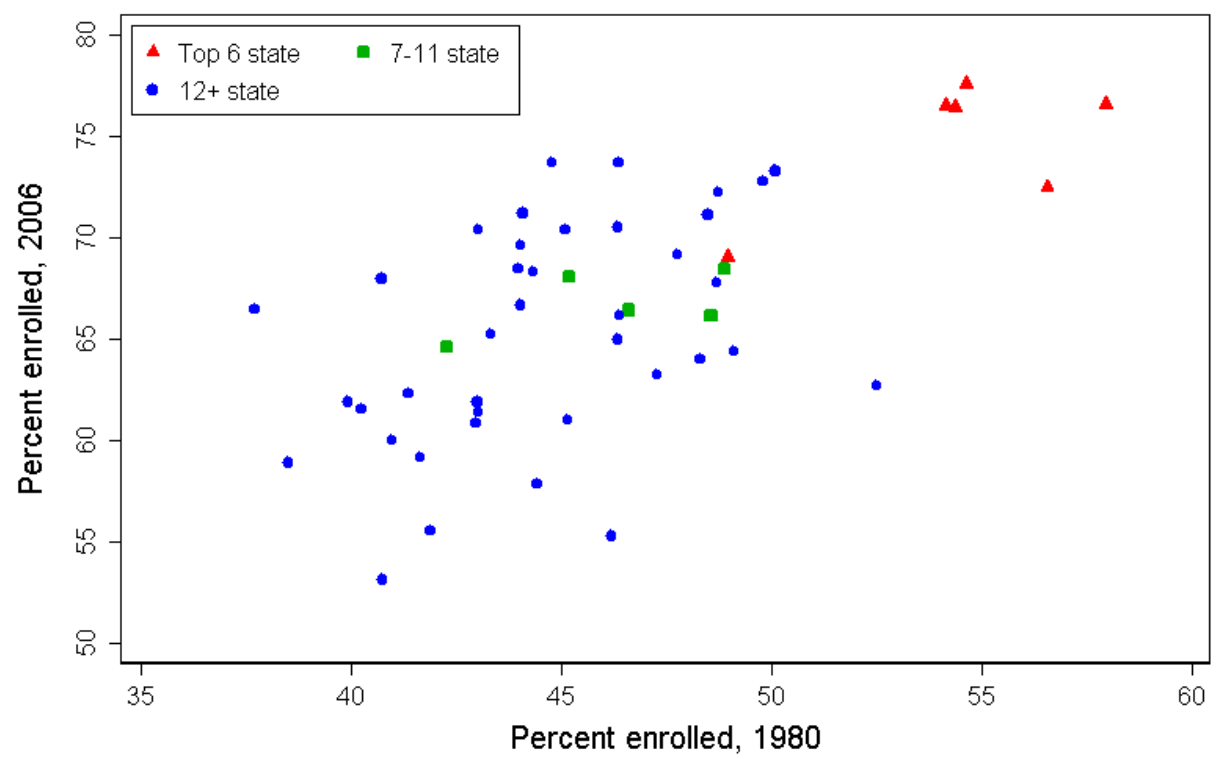

Source: IPUMS data for the 1980 Census and the 2005-2007 American Community Surveys.

Notes: The index of competitive pressure is defined as the sum of the fraction of students who engaged in each of the following in 1992: took the PSAT, took an AP exam, spent 10+ hours on homework per week, used private test preparation services, and applied to five or more colleges. The top six states are NJ, RI, DC, CT, MA, and NY. States seven through eleven are DE, VA, CA, CO, and GA.

Figure 6b: The Effects of Competition on Some College Attainment

Competitive Pressure in High School and Change in Some College, by State

Change of share of 25-year-olds with at least some college between 1980 and 2006

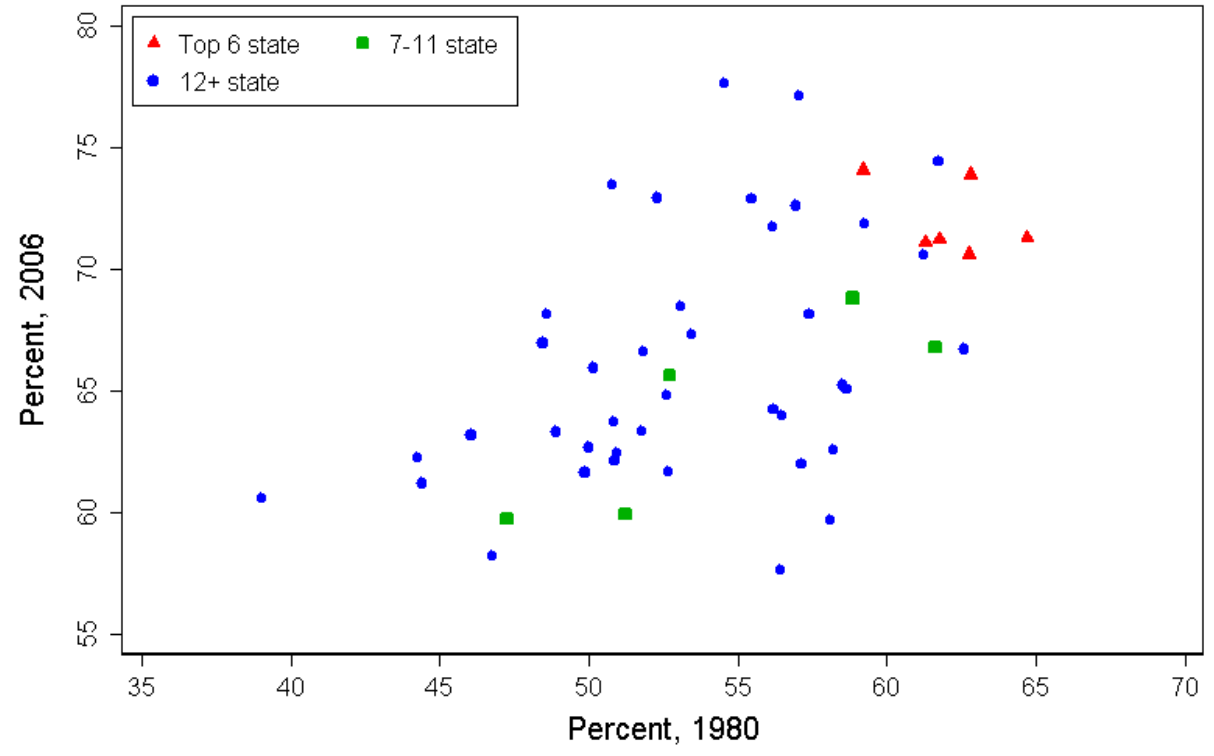

See the source information and notes to Figure 6a. 
Figure 6c: The Effects of Competition on Share with a Bachelor's Degree

Competitive Pressure in High School and Change in Bachelor's Degree, by State

Change of share of 25-year-olds with a bachelor's degree between 1980 and 2006

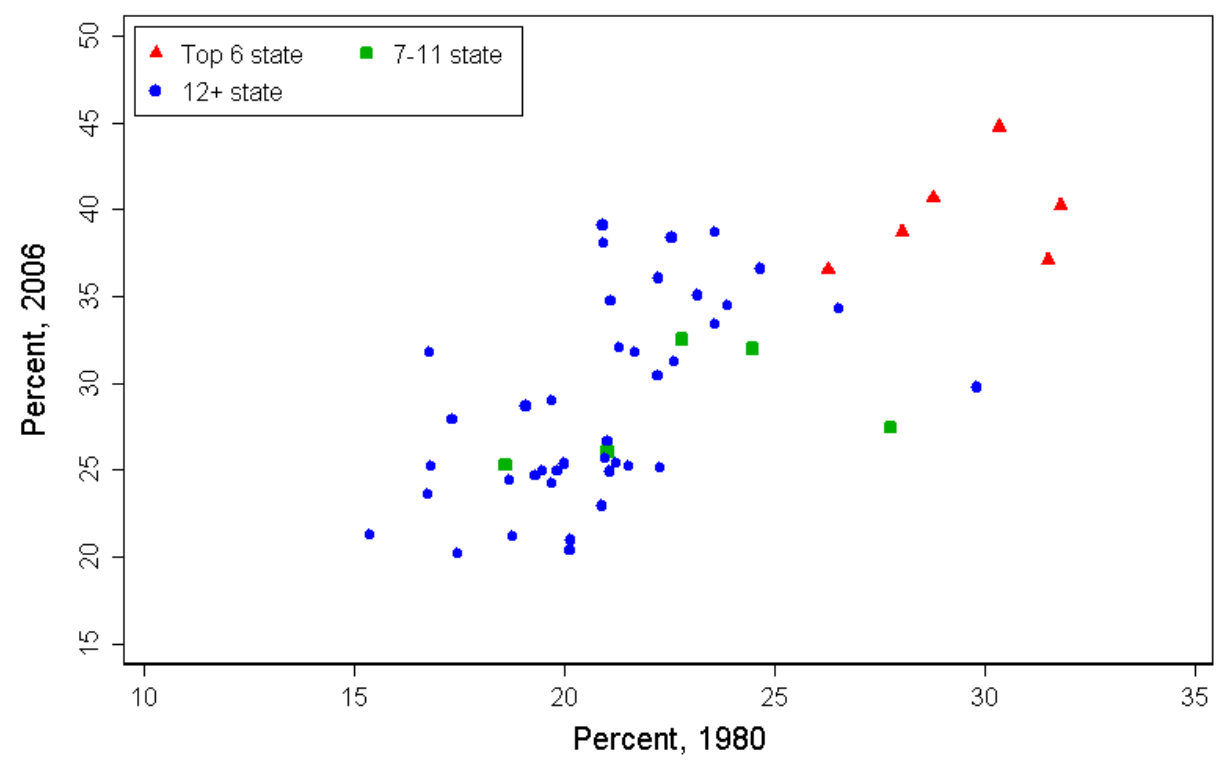

See the source information and notes to Figure 6a.

\section{Figure 6d: The Effects of Competition on Annual Earnings}

Competitive Pressure in High School and Change in Log Real Earnings, by State Change of real log annual earnings of 25-year-olds between 1980 and 2006

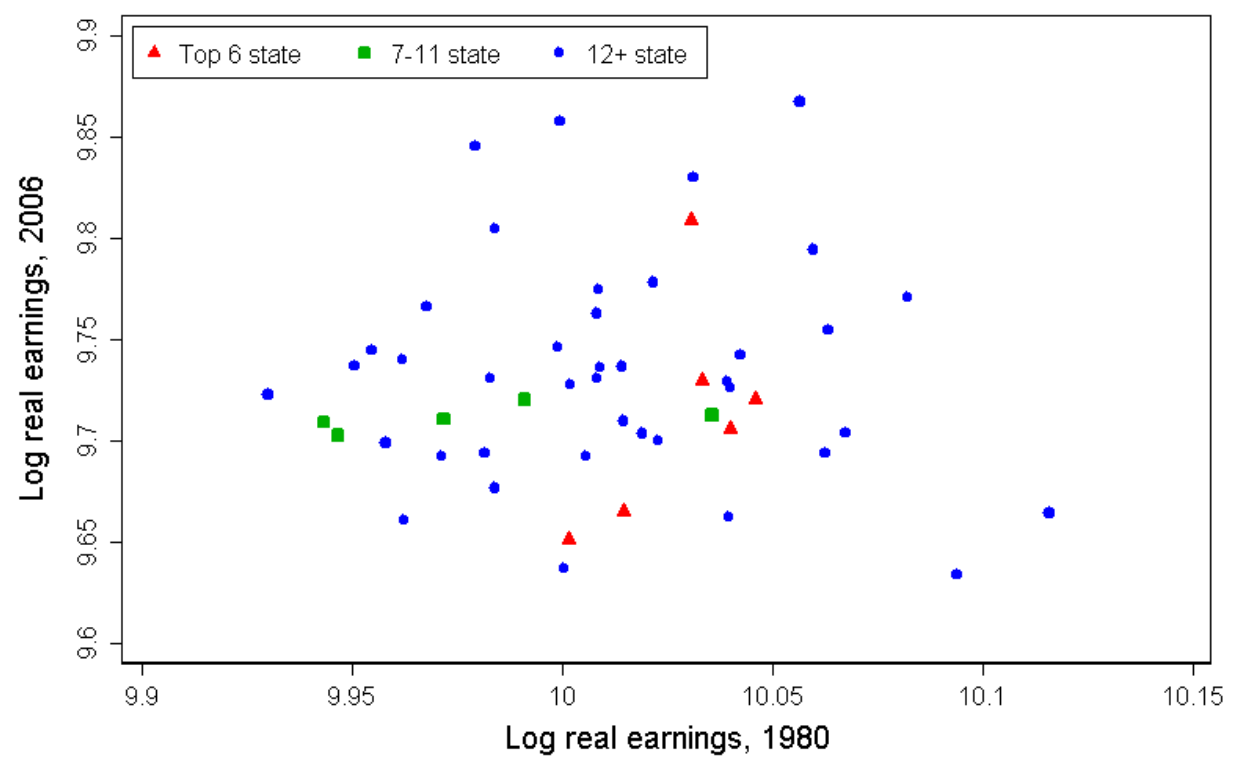

See the source information and notes to Figure 6a. 
Table 1: Supply and Demand Trends in College-Going (thousands)

\begin{tabular}{|c|c|c|c|c|}
\hline & \multicolumn{4}{|c|}{ Year } \\
\hline & 1972 & 1982 & 1992 & 2004 \\
\hline 18-year-olds & 3945 & 4122 & 3347 & 4124 \\
\hline High school graduates & 3002 & 2995 & 2478 & 3064 \\
\hline $\begin{array}{l}\text {...who apply to four-year } \\
\text { colleges }\end{array}$ & 949 & 1184 & 1187 & 1705 \\
\hline $\begin{array}{l}\text {...who attend four-year } \\
\text { colleges in the Fall }\end{array}$ & 910 & 920 & 965 & 1428 \\
\hline $\begin{array}{l}\text {...who apply to selective four- } \\
\text { year private colleges }\end{array}$ & 129 & 149 & 172 & 203 \\
\hline $\begin{array}{l}\ldots \text { who attend selective four- } \\
\text { year private colleges in the Fall }\end{array}$ & 74 & 77 & 86 & 100 \\
\hline $\begin{array}{l}\text {...who apply to selective four- } \\
\text { year public colleges }\end{array}$ & 254 & 271 & 304 & 419 \\
\hline $\begin{array}{l}\text {...who attend selective four- } \\
\text { year public colleges in the Fall }\end{array}$ & 165 & 132 & 150 & 232 \\
\hline
\end{tabular}

Sources: The number of 18-year-olds is from the National Cancer Institute, and the number of high school graduates is from the 2008 Digest of Education Statistics (Table 104). These latter numbers were multiplied by the percentages of high school graduates who met each benchmark according to the authors' calculations using data from the NCES longitudinal surveys.

Notes: Data availability limits application behavior to the top two school choices of respondents; while this measure is consistent across years, it is does not capture a complete profile of application behavior.

Table 2: Percentage Accepted by Sector and Institution Ranking

\begin{tabular}{|c|c|c|c|c|c|c|c|}
\hline & \multicolumn{4}{|c|}{ PRIVATE INSTITUTIONS } & \multicolumn{3}{|c|}{ PUBLIC INSTITUTIONS } \\
\hline & $\begin{array}{l}\text { Top } 20 \\
\text { Privates }\end{array}$ & $\begin{array}{l}\text { Top 21-50 } \\
\text { Universities }\end{array}$ & $\begin{array}{l}\text { Top 21-48 } \\
\text { Liberal Arts }\end{array}$ & $\begin{array}{l}\text { Other Private } \\
\text { Four-years }\end{array}$ & $\begin{array}{c}\text { Top } 20 \\
\text { Universities }\end{array}$ & $\begin{array}{l}\text { Top 21-47 } \\
\text { Universities }\end{array}$ & $\begin{array}{l}\text { Other Public } \\
\text { Four-years }\end{array}$ \\
\hline 1986 & 38.58 & 62.46 & 59.75 & 78.13 & 63.15 & 75.59 & 73.75 \\
\hline 1991 & 38.39 & 67.39 & 57.95 & 76.82 & 56.78 & 73.47 & 68.49 \\
\hline 1996 & 37.55 & 62.41 & 61.85 & 78.73 & 58.98 & 76.53 & 72.96 \\
\hline 2001 & 31.49 & 51.30 & 52.68 & 77.41 & 50.55 & 71.92 & 71.85 \\
\hline 2002 & 30.72 & 49.51 & 51.26 & 75.58 & 48.81 & 71.23 & 71.07 \\
\hline 2003 & 29.85 & 52.35 & 47.88 & 74.35 & 47.72 & 70.56 & 69.19 \\
\hline $\begin{array}{c}\text { Percentage } \\
\text { Change }\end{array}$ & $-22.63 \%$ & $-16.19 \%$ & $-19.87 \%$ & $-4.84 \%$ & $-24.43 \%$ & $-6.65 \%$ & $-6.18 \%$ \\
\hline Num. Schools & 38 & 26 & 28 & 419 & 17 & 21 & 208 \\
\hline
\end{tabular}

Source: American Survey of Colleges, College Board, 1986-87 to 2003-04.

Notes: The Top 20 Private Institutions includes the top 20 private universities and top 20 liberal arts colleges. To be included in the sample, institutions must have had at least 16 of the 18 possible years of data. 
Table 3: Percentage who Applied to Four-Year Institutions, by Cohort and Sector

\begin{tabular}{|c|c|c|c|c|c|c|c|c|c|c|c|c|}
\hline \multirow[b]{2}{*}{ HS Cohort } & \multicolumn{4}{|c|}{$\begin{array}{l}\text { Percentage who Applied to a } \\
\text { Four-year Institution }\end{array}$} & \multicolumn{4}{|c|}{$\begin{array}{l}\text { Percentage who Applied to a Private } \\
\text { Selective Four-year Institution }\end{array}$} & \multicolumn{4}{|c|}{$\begin{array}{l}\text { Percentage who Applied to a Public } \\
\text { Selective Four-year Institution }\end{array}$} \\
\hline & 1972 & 1982 & 1992 & 2004 & 1972 & 1982 & 1992 & 2004 & 1972 & 1982 & 1992 & 2004 \\
\hline U.S. average & 28.8 & 38.2 & 46.5 & 53.2 & 3.9 & 4.8 & 6.7 & 6.2 & 7.5 & 8.8 & 11.9 & 12.8 \\
\hline \multicolumn{13}{|l|}{ Test Quintile } \\
\hline First & 7.9 & 12.3 & 18.2 & 23.8 & 0.4 & 0.1 & 0.7 & 0.7 & 0.7 & 0.7 & 1.7 & 2.5 \\
\hline Second & 14.6 & 19.5 & 32.9 & 37.8 & 0.8 & 0.8 & 1.7 & 1.8 & 2.2 & 2.2 & 5.3 & 4.5 \\
\hline Third & 24.7 & 31.0 & 47.1 & 53.9 & 1.4 & 1.7 & 3.2 & 2.7 & 4.4 & 5.3 & 8.8 & 9.5 \\
\hline Fourth & 38.4 & 51.9 & 64.3 & 67.6 & 3.8 & 4.1 & 7.2 & 5.8 & 9.6 & 12.6 & 16.0 & 18.1 \\
\hline Fifth & 60.7 & 77.8 & 81.7 & 84.8 & 13.6 & 17.0 & 22.8 & 20.4 & 21.3 & 23.8 & 29.3 & 30.1 \\
\hline \multicolumn{13}{|l|}{ Region } \\
\hline New England & 33.1 & 46.7 & 59.5 & 62.9 & 8.3 & 13.9 & 19.9 & 14.4 & 7.9 & 9.0 & 12.5 & 12.3 \\
\hline Middle Atlantic & 32.4 & 40.5 & 55.9 & 59.9 & 7.2 & 9.5 & 14.9 & 10.4 & 6.8 & 7.1 & 12.9 & 12.0 \\
\hline South & 27.3 & 35.4 & 46.0 & 55.2 & 3.4 & 2.1 & 4.3 & 5.4 & 6.2 & 7.5 & 10.6 & 12.7 \\
\hline Midwest & 27.9 & 40.2 & 48.7 & 55.9 & 1.6 & 1.9 & 3.2 & 4.2 & 8.9 & 11.2 & 13.9 & 16.7 \\
\hline Southwest & 32.2 & 37.4 & 39.1 & 49.2 & 2.6 & 1.6 & 3.1 & 2.4 & 5.5 & 6.8 & 8.7 & 7.6 \\
\hline West & 24.0 & 31.6 & 36.7 & 42.5 & 3.1 & 5.1 & 5.8 & 6.0 & 7.6 & 9.2 & 11.3 & 11.1 \\
\hline
\end{tabular}


Table 4: Counterfactual College Acceptance, Conditional on Applying

\begin{tabular}{|c|c|c|c|c|c|c|c|c|c|c|c|c|}
\hline \multirow[b]{2}{*}{ Cohort } & \multicolumn{4}{|c|}{$\begin{array}{l}\text { Percentage who Applied to a } \\
\text { Four-year Institution }\end{array}$} & \multicolumn{4}{|c|}{$\begin{array}{l}\text { Percentage who Applied } \\
\text { to a Private Selective } \\
\text { Four-year Institution }\end{array}$} & \multicolumn{4}{|c|}{$\begin{array}{l}\text { Percentage who Applied } \\
\text { to a Public Selective } \\
\text { Four-year Institution }\end{array}$} \\
\hline & 1972 & 1982 & 1992 & 2004 & 1972 & 1982 & 1992 & 2004 & 1972 & 1982 & 1992 & 2004 \\
\hline U.S. average & 94.2 & 97.6 & 90.7 & 85.9 & 82.5 & 78.5 & 71.3 & 63.9 & 88.4 & 87.9 & 84.9 & 78.9 \\
\hline \multicolumn{13}{|l|}{ Test Quintile } \\
\hline First & 86.4 & 95.9 & 69.4 & 49.7 & - & - & - & - & - & - & - & - \\
\hline Second & 88.9 & 96.6 & 80.9 & 68.2 & - & - & - & - & 71.2 & 71.3 & 68.5 & 50.8 \\
\hline Third & 91.3 & 97.7 & 89.4 & 83.2 & 76.1 & 69.2 & 59.6 & 39.7 & 81.7 & 85.6 & 78.1 & 73.1 \\
\hline Fourth & 93.9 & 98.3 & 93.2 & 89.5 & 73.2 & 87.9 & 67.6 & 59.8 & 88.2 & 86.3 & 78.8 & 73.3 \\
\hline Fifth & 97.9 & 97.6 & 94.8 & 94.0 & 86.1 & 78.9 & 74.7 & 71.5 & 92.0 & 91.7 & 92.6 & 87.6 \\
\hline \multicolumn{13}{|l|}{ Region } \\
\hline New Eng. & 94.7 & 97.6 & 91.8 & 87.8 & 83.0 & 78.8 & 72.6 & 65.4 & 88.9 & 87.5 & 85.6 & 80.0 \\
\hline Mid. Atlan. & 94.8 & 97.7 & 91.7 & 87.7 & 82.3 & 78.6 & 70.7 & 64.1 & 88.7 & 88.9 & 85.9 & 80.2 \\
\hline South & 93.1 & 97.4 & 88.7 & 82.2 & 80.9 & 76.9 & 69.2 & 59.2 & 87.6 & 87.3 & 83.8 & 77.6 \\
\hline Midwest & 94.1 & 97.5 & 90.8 & 86.2 & 84.7 & 80.3 & 73.2 & 69.2 & 88.0 & 87.6 & 84.4 & 78.1 \\
\hline Southwest & 93.4 & 97.5 & 89.1 & 83.2 & 81.2 & 76.3 & 68.4 & 59.7 & 89.9 & 88.5 & 84.5 & 79.3 \\
\hline West & 94.6 & 97.6 & 91.2 & 86.8 & 83.1 & 79.3 & 73.2 & 63.7 & 89.1 & 88.1 & 85.6 & 79.8 \\
\hline
\end{tabular}

Source: National Center for Education Statistics, various longitudinal surveys described in the text.

Notes: Data represent mean fitted probabilities from logistic regressions using the NLS72 data but allowing coefficients to be survey-wave specific. Each number thus represents the mean conditional probability that a student from 1972 in a given cell is admitted to a given college type during the respective survey wave. The covariates used for the regression include only test decile dummies and regional dummies; a version based on a more thorough set of covariates is available in the appendix. Application behavior is based on the top two school choices of respondents. Geography is according to the high school of the student. The test quintile comes from a survey-specific cognitive test battery given to the respondents of each survey during the spring of their senior year; by construction, it is normalized by cohort. (The test batteries are similar but not identical across surveys.) See the Data Appendix for the definitions of selective schools and the regional breakdowns. 
Table 5: Studying, Course-Taking, and AP Exam-taking Behavior (percentages)

\begin{tabular}{|c|c|c|c|c|c|c|c|c|c|}
\hline \multirow[b]{2}{*}{ HS Cohort } & \multicolumn{3}{|c|}{$\begin{array}{c}\text { Took High School } \\
\text { Calculus }\end{array}$} & \multicolumn{2}{|c|}{$\begin{array}{l}\text { Took an AP } \\
\text { exam }\end{array}$} & \multicolumn{4}{|c|}{ Homework time: $10+$ hours/weel } \\
\hline & 1982 & 1992 & 2004 & 1992 & 2004 & 1972 & 1982 & 1992 & 2004 \\
\hline U.S. average & 9.2 & 10.3 & 15.2 & 16.5 & 30.9 & 5.5 & 10.2 & 26.7 & 20.4 \\
\hline \multicolumn{10}{|l|}{ Test Quintile } \\
\hline First & 2.0 & 0.3 & 4.0 & 3.4 & 13.7 & 2.7 & 4.6 & 15.1 & 10.3 \\
\hline Second & 1.8 & 1.2 & 3.8 & 6.2 & 14.6 & 2.9 & 5.3 & 20.0 & 15.4 \\
\hline Third & 2.4 & 3.7 & 5.5 & 8.6 & 24.6 & 4.2 & 7.5 & 22.5 & 17.8 \\
\hline Fourth & 7.9 & 10.1 & 13.2 & 16.9 & 36.6 & 6.5 & 11.9 & 30.1 & 23.1 \\
\hline Fifth & 31.5 & 38.7 & 49.9 & 49.0 & 66.2 & 11.6 & 21.3 & 39.4 & 35.9 \\
\hline \multicolumn{10}{|l|}{ Application Status } \\
\hline Four-year school & 19.7 & 19.2 & 23.3 & 27.5 & 44.8 & 10.0 & 18.4 & 34.7 & 27.4 \\
\hline Selective Private & 43.9 & 43.6 & 52.3 & 60.0 & 77.9 & 17.6 & 38.7 & 49.5 & 45.2 \\
\hline Selective Public & 26.6 & 29.4 & 36.8 & 39.7 & 60.8 & 13.2 & 22.7 & 40.0 & 33.7 \\
\hline \multicolumn{10}{|l|}{ Region } \\
\hline New England & 15.4 & 15.8 & 19.3 & 19.0 & 31.6 & 6.3 & 16.8 & 35.8 & 23.7 \\
\hline Middle Atlantic & 13.8 & 13.8 & 18.2 & 20.6 & 31.7 & 6.0 & 12.1 & 25.8 & 18.6 \\
\hline South & 6.4 & 9.5 & 15.2 & 17.4 & 32.9 & 6.0 & 7.5 & 25.4 & 17.7 \\
\hline Midwest & 8.2 & 8.9 & 14.8 & 13.0 & 26.9 & 5.2 & 9.6 & 25.2 & 19.4 \\
\hline Southwest & 4.6 & 10.3 & 13.2 & 10.8 & 31.7 & 4.0 & 5.3 & 23.3 & 16.1 \\
\hline West & 8.0 & 9.1 & 13.3 & 19.5 & 32.6 & 5.5 & 12.4 & 30.8 & 26.7 \\
\hline
\end{tabular}

Source: National Center for Education Statistics, longitudinal surveys (NLS72, HSB82, NELS92, ELS04). The cohort year refers to the year on-time students would have graduated high school.

Notes: The universe is high school seniors in the year designated for each cohort, and all figures are weighted to match the population universe. The test quintile comes from a survey-specific cognitive test battery given to the respondents of each survey during the spring of their senior year; by construction, it is normalized by cohort. (The test batteries are similar but not identical across surveys.) See the Data Appendix for the definitions of selective schools and the regional breakdowns. Application status refers to the types of colleges to which the respondent applied, and it is non-exclusive. Calculus and AP taking are based on students' self reports in the survey. Homework time is also based on self reports with categorical answers; the categories can consistently be aggregated across survey cohorts to construct a 10+ hour per week measure. 
Table 6: College Exam Test-Taking and Preparation (percentages)

\begin{tabular}{|c|c|c|c|c|c|c|c|c|}
\hline \multirow[b]{2}{*}{ HS Cohort } & \multicolumn{4}{|c|}{ Took SAT or ACT } & \multicolumn{2}{|c|}{$\begin{array}{c}\text { Test Prep: Private } \\
\text { Class/Tutoring }\end{array}$} & \multicolumn{2}{|c|}{$\begin{array}{c}\text { Test Preparation: } \\
\text { Any form }\end{array}$} \\
\hline & 1972 & 1982 & 1992 & 2004 & 1992 & 2004 & 1992 & 2004 \\
\hline U.S. average & 47.7 & 56.1 & 61.0 & 64.6 & 14.1 & 18.1 & 59.7 & 62.6 \\
\hline \multicolumn{9}{|l|}{ Test Quintile } \\
\hline First & 13.5 & 29.2 & 25.2 & 34.3 & 18.4 & 19.2 & 48.2 & 48.2 \\
\hline Second & 30.4 & 38.4 & 46.3 & 51.1 & 11.7 & 16.0 & 58.7 & 58.1 \\
\hline Third & 48.4 & 50.8 & 65.6 & 69.5 & 12.5 & 16.7 & 62.4 & 66.8 \\
\hline Fourth & 64.8 & 70.7 & 80.3 & 80.3 & 11.7 & 18.0 & 66.9 & 68.1 \\
\hline Fifth & 82.0 & 90.5 & 89.5 & 88.8 & 15.2 & 20.3 & 65.9 & 69.7 \\
\hline \multicolumn{9}{|l|}{ Application Status } \\
\hline Four-year school & 85.8 & 91.7 & 89.8 & 87.4 & 17.7 & 23.1 & 72.7 & 76.5 \\
\hline Selective Private & 96.5 & 98.1 & 95.2 & 90.0 & 32.8 & 36.4 & 80.4 & 83.0 \\
\hline Selective Public & 89.6 & 95.9 & 92.9 & 88.6 & 18.0 & 27.0 & 74.0 & 76.8 \\
\hline \multicolumn{9}{|l|}{ Region } \\
\hline New England & 57.9 & 63.7 & 74.1 & 68.2 & 19.1 & 19.4 & 60.5 & 58.7 \\
\hline Middle Atlantic & 58.3 & 57.3 & 70.0 & 66.6 & 19.4 & 20.9 & 64.4 & 67.6 \\
\hline South & 41.9 & 54.6 & 59.2 & 68.7 & 14.2 & 21.4 & 61.9 & 69.3 \\
\hline Midwest & 46.3 & 57.2 & 64.9 & 71.1 & 8.7 & 13.9 & 55.0 & 59.7 \\
\hline Southwest & 49.3 & 54.7 & 51.9 & 63.6 & 17.6 & 17.2 & 63.9 & 62.6 \\
\hline West & 36.9 & 51.4 & 51.9 & 50.7 & 13.4 & 17.4 & 57.4 & 55.0 \\
\hline
\end{tabular}

Source: National Center for Education Statistics, longitudinal surveys (NLS72, HSB82, NELS92, ELS04). The cohort year refers to the year on-time students would have graduated high school.

Notes: The universe is high school seniors in the year designated for each cohort, and all figures are weighted to match the population universe. The test quintile comes from a survey-specific cognitive test battery given to the respondents of each survey during the spring of their senior year; by construction, it is normalized by cohort. (The test batteries are similar but not identical across surveys.) See the Data Appendix for the definitions of selective schools and the regional breakdowns. Application status refers to the types of colleges to which the respondent applied, and it is non-exclusive. SAT/ACT test taking are (each) based on students' self reports, as are the test preparation questions; "any form" of test preparation includes private classes/tutoring, classes offered by the high school, and self study using books, video, or computer software. 
Table 7: Fraction of Students who Sent at least 6, 8, 10 or 15 SAT Scores Reports by Score

\begin{tabular}{lrcccccc}
\hline \hline & \multicolumn{7}{c}{ SAT SCORE RANGE } \\
\cline { 2 - 8 } & $\begin{array}{r}900- \\
990\end{array}$ & $\begin{array}{c}1000- \\
1090\end{array}$ & $\begin{array}{c}1100- \\
1190\end{array}$ & $\begin{array}{c}1200- \\
1290\end{array}$ & $\begin{array}{c}1300- \\
1390\end{array}$ & $\begin{array}{c}1400- \\
1490\end{array}$ & $\begin{array}{c}1500- \\
1600\end{array}$ \\
\hline \hline 6+ Scores & 0.244 & 0.295 & 0.370 & 0.461 & 0.570 & 0.680 & 0.783 \\
$8+$ Scores & 0.095 & 0.128 & 0.178 & 0.251 & 0.343 & 0.450 & 0.560 \\
$10+$ Scores & 0.032 & 0.048 & 0.076 & 0.117 & 0.177 & 0.247 & 0.318 \\
$15+$ Scores & 0.003 & 0.004 & 0.008 & 0.014 & 0.023 & 0.035 & 0.045 \\
\hline \hline
\end{tabular}

Source: Tabulations by Jesse Rothstein of College Board microdata of SAT takers.

Notes: The sample is restricted to states in which students primarily take the SAT. (See Data Appendix for a definition and list of SAT states) The data cover SAT I tests taken in the period 1996 through 2001. The test allows up to four score reports to be sent at no charge beyond the test fee. 
Table 8: Effects of Competitive Pressure on Social Outcomes

\begin{tabular}{|c|c|c|c|c|}
\hline \multirow[t]{2}{*}{ Panel A: (in logs) } & $\begin{array}{l}\text { College } \\
\text { enrollment } \\
\text { age } 19\end{array}$ & $\begin{array}{l}\text { Some college } \\
\text { age } 25\end{array}$ & $\begin{array}{l}\text { Bachelor’s } \\
\text { degree } \\
\text { age } 25\end{array}$ & $\begin{array}{l}\text { Real earnings } \\
\text { age } 25\end{array}$ \\
\hline & $(1)$ & (2) & (3) & (4) \\
\hline $\begin{array}{l}\text { Differential trend } \\
\text { (x100), Top } 6 \text { states }\end{array}$ & $\begin{array}{c}-0.23 * * * \\
(0.08)\end{array}$ & $\begin{array}{c}-0.25^{* * *} \\
(0.09)\end{array}$ & $\begin{array}{l}-0.00 \\
(0.15)\end{array}$ & $\begin{array}{l}-0.14^{*} \\
(0.08)\end{array}$ \\
\hline $\begin{array}{l}\text { Differential trend } \\
\text { (x100), Top } 11 \text { states }\end{array}$ & $\begin{array}{l}-0.15^{*} \\
(0.08)\end{array}$ & $\begin{array}{c}-0.23^{* * *} \\
(0.08)\end{array}$ & $\begin{array}{l}-0.16 \\
(0.16)\end{array}$ & $\begin{array}{l}-0.05 \\
(0.07)\end{array}$ \\
\hline Observations & 102 & 102 & 102 & 102 \\
\hline \multirow[t]{2}{*}{ Panel B: } & All Ph.D.s & $\begin{array}{c}\text { All science \& } \\
\text { engineering } \\
\text { Ph.D.s } \\
\end{array}$ & $\begin{array}{l}\text { Ph.D.s from top } \\
\text { schools }\end{array}$ & $\begin{array}{c}\text { Science \& } \\
\text { engineering Ph.D.s } \\
\text { from top schools }\end{array}$ \\
\hline & (5) & (6) & (7) & (8) \\
\hline $\begin{array}{l}\text { Differential trend } \\
\text { (x100), Top } 6 \text { states }\end{array}$ & $\begin{array}{l}-0.28 \\
(0.32)\end{array}$ & $\begin{array}{c}-0.94 * * * \\
(0.34)\end{array}$ & $\begin{array}{l}-0.83 \\
(0.56)\end{array}$ & $\begin{array}{l}-1.11^{*} \\
(0.66)\end{array}$ \\
\hline $\begin{array}{l}\text { Differential trend } \\
\text { (x100), Top } 10 \text { states }\end{array}$ & $\begin{array}{l}-0.34 \\
(0.25)\end{array}$ & $\begin{array}{c}-0.91 * * * \\
(0.30)\end{array}$ & $\begin{array}{c}-0.92 * * \\
(0.33)\end{array}$ & $\begin{array}{c}-1.11^{* * *} \\
(0.38)\end{array}$ \\
\hline Observations & 1217 & 1224 & 1224 & 1224 \\
\hline \multicolumn{5}{|c|}{ 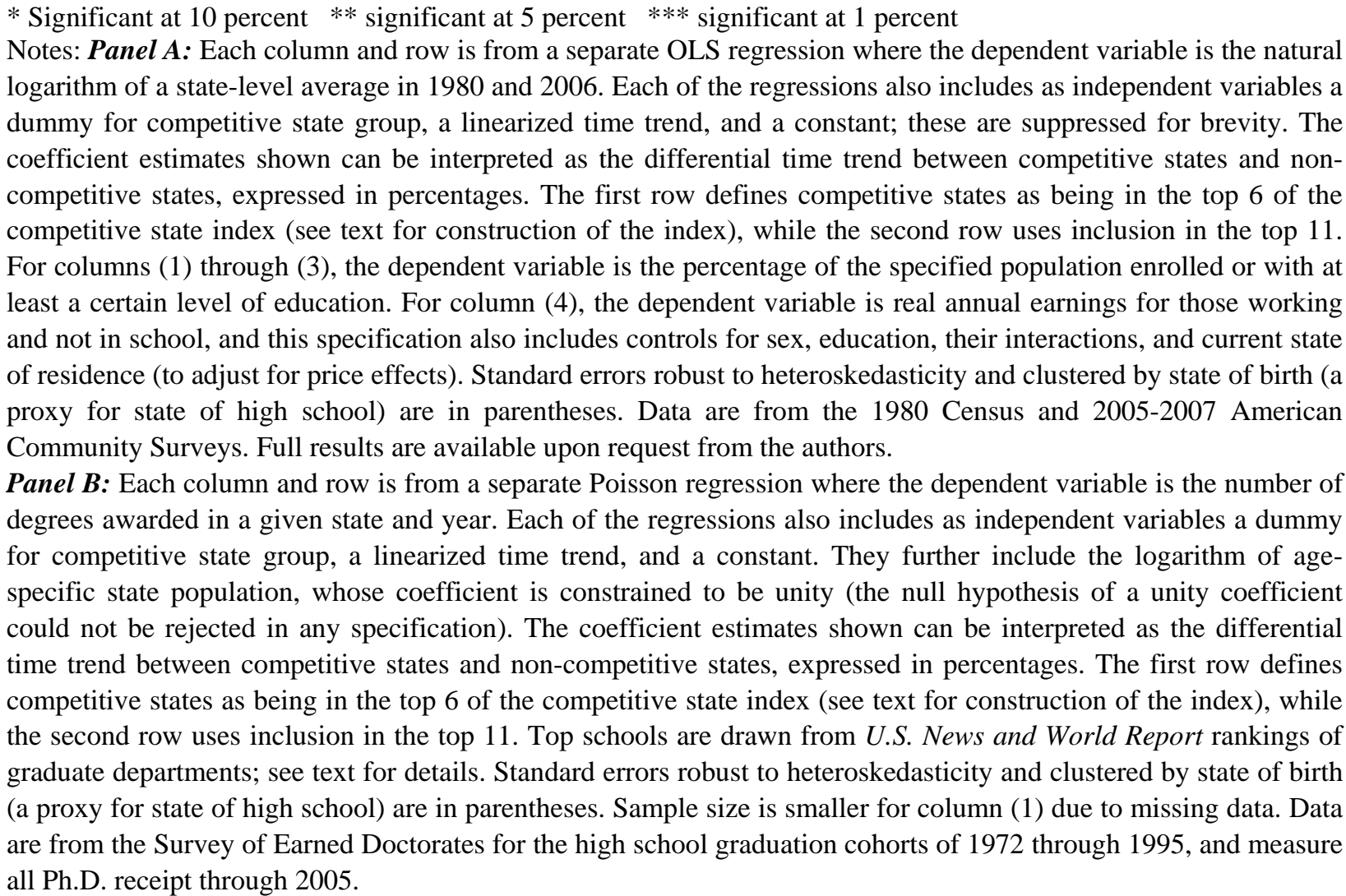 } \\
\hline
\end{tabular}




\section{DATA APPENDIX}

In this article, we draw upon several data sources, including student-level surveys from the National Center of Education Statistics (NCES), institution-level data from the Integrated Postsecondary Educational Database System (IPEDS) and the Annual Survey of Colleges (ASC), and other data on college entrance examinations and degree attainment. In this data appendix, we describe these datasets in more detail and discuss issues of sample restrictions, dataset comparability, and important variable definitions.

\section{Institutional Data: American Survey of Colleges}

The American Survey of Colleges (ASC) is a near-census of four-year postsecondary educational institutions in the United States, conducted by the College Board. Containing detailed data on institutional classification, enrollment, applications, student body profiles, expenditures, and sources of funding, the ASC is ideal for examining trends in characteristics among different types of institutions. Our data run from 1986 through 2003. Missing data prevented us from using more recent years. Summary statistics for our sample are available in Appendix Table 1.

\section{College Ranking Measure}

In constructing our selectivity measures, we generally follow the methodology of Bound, Lovenheim, and Turner (2007), who in turn employ the rankings from the 2005 edition of U.S. News and World Report's Best Colleges. Selective private schools include the top 50 private research universities as well as the top 49 liberal arts colleges. Selective public schools include the top 47 public universities. These schools are listed in Appendix Table 2.

\section{Student Data: National Center of Education Statistics Longitudinal Student Datasets}

The National Center of Education Statistics (NCES) has conducted four nationallyrepresentative, large-scale, longitudinal surveys of secondary students since 1972. Each of these surveys originally sampled between 12,000 and 16,000 students in a given grade cohort, with followup survey waves over the next several years. Designed to shed light on the school-to-work transition, the surveys ask questions about demographic background, school experiences, education and work expectations, and labor market outcomes. Additionally, each survey cohort was administered a cognitive test battery. In many cases, the data variables are directly comparable across the four different surveys.

These data allow us to construct measures of high school behavior, such as course-taking, test preparation, extracurriculars, and time spent on homework. Using the restricted-access versions of these datasets, we can also identify the top two choices of schools to which students applied and whether they were accepted. We condition our sample using inverse probability sampling weights to be nationally representative of the relevant high school senior classes. ${ }^{21}$ Summary statistics for each cohort are provided in Appendix Table 4.

- National Longitudinal Study of the High School Class of 1972 (NLS)

The first NCES student panel study, the NLS surveyed approximately 17,000 high school seniors in the spring of 1972, with follow-up waves in 1973, 1974, 1979, and 1986. We use the initial

\footnotetext{
${ }^{21}$ Because the NCES surveys initially sample the cohorts at different ages, we use the provided flags and probability weights that are meant to represent the universe of U.S. high school seniors. These flags and weights are described below.
} 
and 1973 waves. $^{22}$ The weight variable is W4, and the universe is already high school seniors, so no additional sample flag is necessary.

- High School and Beyond (HSB)

The second longitudinal study originally surveyed both $10^{\text {th }}$ and 12th graders in 1980 (approximately 14,000 of each), with follow-ups in 1982, 1984, and 1986. Due to the richer high school data available for the sophomore cohort, we restrict our sample from the HSB to the sophomore cohort and use the 1982 and 1984 waves. The weight variable used is FU2WT, and the conditioning flags are FU1PART and FU2PART.

- $\quad$ National Educational Longitudinal Survey (NELS)

The third NCES panel study surveyed approximately $25,0008^{\text {th }}$ graders in 1988 , with follow-up waves in 1990, 1992, 1994, and 2000. Using the 1992 and 1994 waves, the weight variable F3QWTG12, and the conditioning flag G12COHRT, our NELS sample is representative of the high school senior class of 1992.

- $\quad$ Educational Longitudinal Survey (ELS)

The fourth and newest longitudinal student survey, the ELS, initially surveyed approximately $15,00010^{\text {th }}$ graders in 2002 and has since conducted follow-ups in 2004 and 2006. Using the 2004 and 2006 waves, the weight variable F1QWT, and the conditioning flag F1UNIV2B, our ELS sample is representative of the high school class of 2004.

In general, item non-response in the NCES surveys for the measures used in this article was minor, often less than 5 percent of the sample. The main exception is for the cognitive test battery, a variable used for stratification of the other indicators, in the NELS92 survey. Rather than item nonresponse, per se, missing test battery scores result from students who were not administered the test battery (generally because they were not in school when the battery was administered and arrangements could not be made to re-test them). In the NELS, 20.6 percent of the eligible sample is missing a test battery score. ${ }^{23}$ However, a simple OLS regression showed almost no correlation between socioeconomic status and the likelihood of missing a test battery score. While this does not obviate the possibility of other latent correlates, it suggests bias in the results by test quintile is probably small. Consequently, Tables 2 through 5 treat this problem as ignorable.

\section{HERI CIRP Freshman Survey}

The Cooperative Institutional Research Program (CIRP) at the University of California, Los Angeles's Higher Education Research Institute (HERI) has conducted an annual, large-scale survey of college freshmen since the mid 1960s. The survey is administered to approximately 400,000 students at 300 to 400 participating schools each year and asks about many student characteristics, including demographic background, secondary school achievement and activities, educational and career plans, and college application behavior. We use aggregated, annual data that are weighted to be nationally representative of all first-year students at four-year colleges and universities, as published in selected editions of The American Freshman (1991, 1996, 2000, and 2004) and The American Freshman: Forty Year Trends. As individual institution-level identifiers are not available,

\footnotetext{
${ }^{22}$ As in all of the NCES surveys here, new individuals were often added in some of the later waves. We focus on individuals who were in the waves that coincide with the senior year of high school and the wave immediately following.

${ }^{23}$ In the NLS, 4.9 percent of the sample is missing a score; in the HSB, 1.3 percent is missing a score; and in the ELS, 0 percent is missing a score.
} 
we use the selectivity measures provided in the survey (which are based on mean SAT scores or equivalents of the entering class), aggregated across institution type. For more information about the Freshman Survey, see: http://www.gseis.ucla.edu/heri/cirpoverview.php

\section{SAT and AP Exam Data}

The College Board provides the number of SAT tests and AP exams taken each year by the students of each state. ${ }^{24}$ With population data at the state, single-year-of-age level from the National Cancer Institute's Surveillance Epidemiology and End Results (SEER) program (http://seer.cancer.gov/popdata/), we construct the test-taking rates. The data on score sending by SAT and ACT score band were kindly provided by Jesse Rothstein and Amanda Pallais, respectively.

\section{SAT states}

As mentioned in the text, the SAT is prevalent in some states, while the ACT is prevalent in others. We define an SAT state to be one in which the SAT participation rate weakly exceeds the national average in 2007 (43.7 percent). ${ }^{25}$ The resulting set of SAT states comprises: Alaska, California, Connecticut, Delaware, Florida, Georgia, Hawaii, Indiana, Maine, Maryland, Massachusetts, New Hampshire, New Jersey, New York, North Carolina, Oregon, Pennsylvania, Rhode Island, South Carolina, Texas, Vermont, Virginia, Washington, and the District of Columbia.

\section{Geographical Definitions}

The geographic regions we use in this article are based on the classification used in the American Survey of Colleges (ASC). They are defined as follows:

- New England: Connecticut, Maine, Massachusetts, New Hampshire, Rhode Island, and Vermont.

- Middle Atlantic States: Delaware, Maryland, New Jersey, New York, Pennsylvania, and Washington, D.C.

- South: Alabama, Florida, Georgia, Kentucky, Louisiana, Mississippi, North Carolina, South Carolina, Tennessee, and Virginia.

- Midwest: Illinois, Indiana, Iowa, Kansas, Michigan, Minnesota, Missouri, Nebraska, North Dakota, Ohio, South Dakota, West Virginia, and Wisconsin

- Southwest: Arkansas, New Mexico, Oklahoma, and Texas.

- West: Alaska, Arizona, California, Colorado, Hawaii, Idaho, Montana, Nevada, Oregon, Utah, Washington, and Wyoming.

\footnotetext{
${ }^{24}$ The SAT data are for the high school graduating class of the specified year, while the AP data are for all exams administered in the specified year, regardless of cohort. See http://professionals.collegeboard.com/data-reportsresearch/sat/cb-seniors-2008 and http://professionals.collegeboard.com/data-reports-research/ap/nation for more information.

${ }^{25}$ The SAT participation rate in turn is constructed by dividing the number of test takers by state and cohort, as provided by the College Board, by the estimated number of high school graduates, as provided by WICHE (1998, 2008). The set of SAT states is not sensitive to using a different year cutoff.
} 


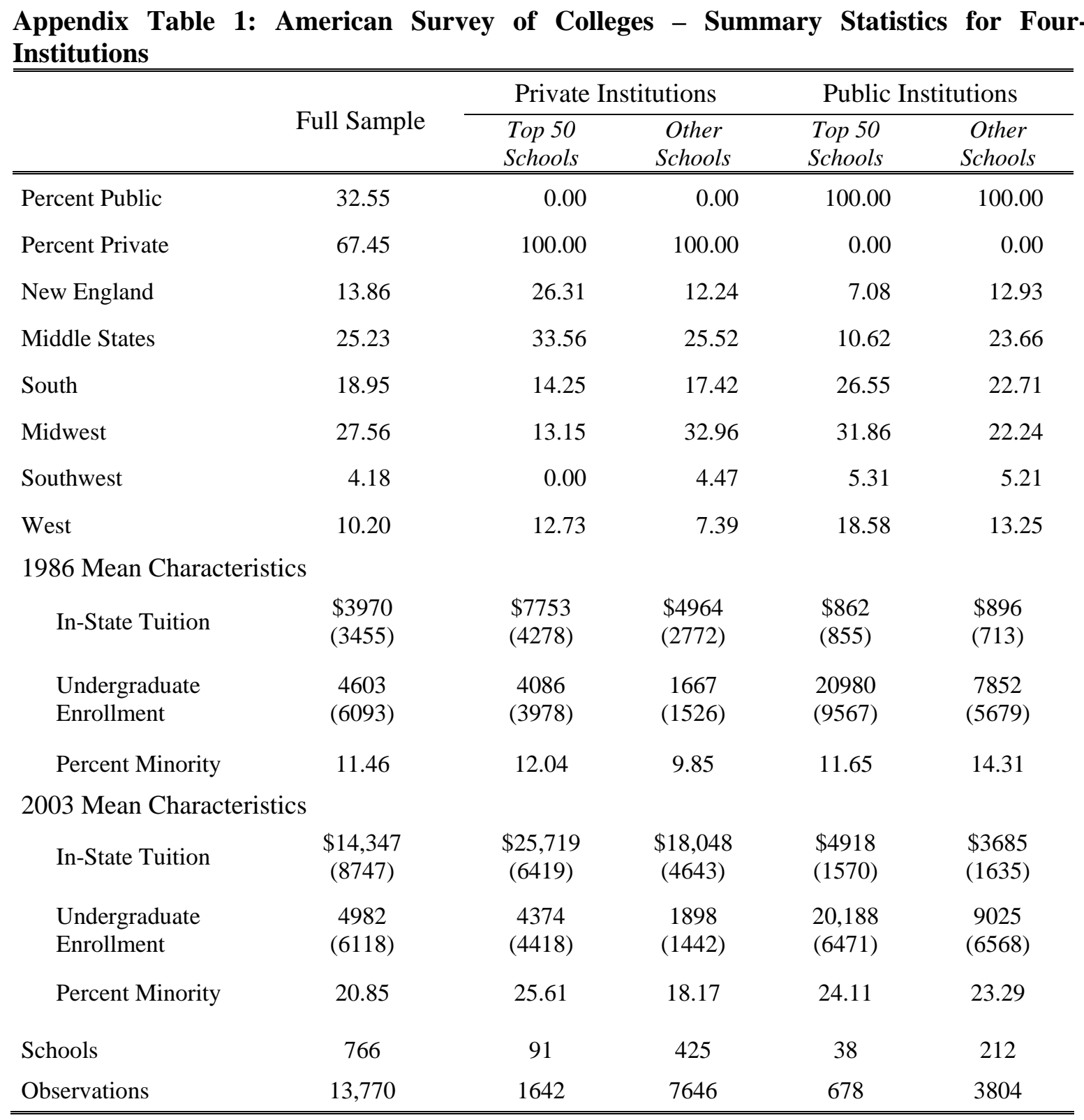

Source: American Survey of Colleges, College Board, 1986-87 to 2003-04.

Notes: The Top 50 Private Institutions includes the top 50 private universities and top 49 liberal arts colleges. To be included in the sample, institutions must have had at least 16 of the 18 possible years of data. The regional statistics are percentages. 


\section{Appendix Table 2: Most Selective Four-year Colleges and Universities}

\begin{tabular}{|c|c|c|}
\hline Top 50 Private Universities & Top 49 Private Liberal Arts Colleges & Top 47 Public Universities \\
\hline American & Amherst & Auburn Univ. \\
\hline Baylor & Bard & Clemson Univ. \\
\hline Boston College & Barnard & Coll. of William and Mary \\
\hline Boston Univ. & Bates & Georgia Tech \\
\hline Brandeis & Bowdoin & Indiana Univ., Bloomington \\
\hline Brigham Young & Bryn Mawr & Iowa State Univ. \\
\hline Brown & Bucknell & Miami Univ. \\
\hline Cal Tech & Carleton & Michigan State Univ. \\
\hline Carnegie Mellon & Centre & N. Carolina State Univ. \\
\hline Case Western Reserve & Claremont McKenna & Ohio State Univ. \\
\hline Clark & Colby & Ohio Univ. \\
\hline Columbia & Colgate & Pennsylvania State Univ. \\
\hline Cornell & Colorado Coll. & Purdue Univ. \\
\hline Dartmouth & Connecticut Coll. & Rutgers, New Brunswick \\
\hline Duke & Davidson & SUNY, Binghamton \\
\hline Emory & DePauw & Texas A\&M \\
\hline Fordham & Dickinson & Univ. of California, San Diego \\
\hline George Washington & Franklin and Marshall & Univ. of Arizona \\
\hline Georgetown & Furman & Univ. of California, Berkeley \\
\hline Harvard & Gettysburg & Univ. of California, Davis \\
\hline Howard & Grinnell & Univ. of California, Irvine \\
\hline Johns Hopkins & Hamilton Coll. & Univ. of California, Los Angeles \\
\hline Lehigh & Harvey Mudd & Univ. of California, Riverside \\
\hline MIT & Haverford & Univ. of California, Santa Barbara \\
\hline New York Univ. & Holy Cross & Univ. of California, Santa Cruz \\
\hline Northwestern & Kenyon & Univ. of Colorado, Boulder \\
\hline Notre Dame & Lafayette Coll. & Univ. of Connecticut \\
\hline Pepperdine & Macalester & Univ. of Delaware \\
\hline Princeton & Middlebury & Univ. of Florida \\
\hline Rensselaer Polytechnic & Mount Holyoke & Univ. of Georgia \\
\hline Rice & Oberlin & Univ. of IL, Urbana-Champaign \\
\hline Southern Methodist & Occidental & Univ. of Iowa \\
\hline St. Louis University & Pitzer & Univ. of Kansas \\
\hline Stanford & Pomona & Univ. of Maryland, College Park \\
\hline Stevens Inst. of Technology & Rhodes Coll. & Univ. of Massachusetts, Amherst \\
\hline Syracuse & Richmond & Univ. of Michigan \\
\hline Tufts & Scripps & Univ. of Minnesota, Twin Cities \\
\hline Tulane & Sewanee & Univ. of Missouri, Columbia \\
\hline Univ. of Chicago & Skidmore & Univ. of N. Carolina, Chapel Hill \\
\hline Univ. of Miami & Smith & Univ. of Nebraska, Lincoln \\
\hline Univ. of Pennsylvania & Swarthmore & Univ. of New Hampshire \\
\hline Univ. of Pittsburgh & Trinity Coll. & Univ. of Tennessee \\
\hline Univ. of Rochester & Union & Univ. of Texas, Austin \\
\hline Univ. of Southern California & Vassar & Univ. of Vermont \\
\hline Vanderbilt & Washington and Lee & Univ. of Virginia \\
\hline Wake Forest & Wellesley & Univ. of Washington \\
\hline Washington Univ. (St. Louis ) & Wesleyan & Univ. of Wisconsin, Madison \\
\hline Worcester Polytechnic & Whitman & \\
\hline Yale & Williams & \\
\hline Yeshiva & & \\
\hline
\end{tabular}

Source: Bound, Lovenheim, and Turner (2007) who in turn employ the rankings from the 2005 edition of U.S. News and World Report's Best Colleges. 
Appendix Table 3: Counterfactual College Acceptance, Conditional on Applying

\begin{tabular}{|c|c|c|c|c|c|c|c|c|c|c|c|c|}
\hline \multirow[b]{2}{*}{ HS Cohort } & \multicolumn{4}{|c|}{$\begin{array}{c}\text { Percentage who Applied to a } \\
\text { Four-year Institution }\end{array}$} & \multicolumn{4}{|c|}{$\begin{array}{c}\text { Percentage who Applied } \\
\text { to a Private Selective } \\
\text { Four-year Institution }\end{array}$} & \multicolumn{4}{|c|}{$\begin{array}{c}\text { Percentage who Applied } \\
\text { to a Public Selective } \\
\text { Four-year Institution }\end{array}$} \\
\hline & 1972 & 1982 & 1992 & 2004 & 1972 & 1982 & 1992 & 2004 & 1972 & 1982 & 1992 & 2004 \\
\hline U.S. average & 94.7 & 98.0 & 91.3 & 88.8 & 84.1 & 81.4 & 71.6 & 62.7 & 88.4 & 86.3 & 86.3 & 82.6 \\
\hline \multicolumn{13}{|l|}{ Test Quintile } \\
\hline First & 88.5 & 94.9 & 75.0 & 64.3 & - & - & - & - & - & - & - & - \\
\hline Second & 88.0 & 95.4 & 81.8 & 73.8 & - & - & - & - & 70.9 & 63.1 & 65.4 & 61.7 \\
\hline Third & 92.1 & 98.2 & 89.4 & 84.6 & 78.0 & 65.7 & 52.5 & 53.7 & 83.8 & 83.4 & 78.3 & 78.6 \\
\hline Fourth & 94.2 & 98.7 & 92.9 & 90.2 & 74.6 & 87.3 & 64.5 & 52.9 & 87.4 & 88.1 & 79.7 & 74.2 \\
\hline Fifth & 97.8 & 98.2 & 94.1 & 94.3 & 87.6 & 81.5 & 75.7 & 68.9 & 91.8 & 89.1 & 93.3 & 89.7 \\
\hline \multicolumn{13}{|l|}{ Region } \\
\hline New England & 85.5 & 97.3 & 95.5 & 89.0 & 76.1 & 78.8 & 72.1 & 62.6 & 79.7 & 68.9 & 89.6 & 86.0 \\
\hline Mid. Atlantic & 92.7 & 97.2 & 90.0 & 90.1 & 87.4 & 78.3 & 68.1 & 62.0 & 84.8 & 78.1 & 81.5 & 83.2 \\
\hline South & 97.2 & 97.5 & 91.3 & 86.5 & 85.7 & 87.9 & 75.9 & 62.4 & 82.5 & 91.8 & 83.8 & 74.0 \\
\hline Midwest & 98.1 & 99.4 & 94.6 & 90.9 & 86.2 & 81.8 & 73.3 & 71.3 & 94.4 & 91.9 & 88.3 & 86.9 \\
\hline Southwest & 95.3 & 99.6 & 86.7 & 83.7 & 79.0 & 89.0 & 81.0 & 67.7 & 88.2 & 93.7 & 79.6 & 88.2 \\
\hline West & 94.0 & 96.7 & 86.7 & 86.6 & 78.1 & 84.1 & 73.2 & 55.3 & 89.0 & 86.0 & 89.6 & 76.5 \\
\hline
\end{tabular}

Source: National Center for Education Statistics, longitudinal surveys (NLS72, HSB82, NELS92, ELS04). The cohort year refers to the year on-time students would have graduated high school.

Notes: Data represent mean fitted probabilities from logistic regressions using the NLS72 data but allowing coefficients to be survey-wave specific. Each number thus represents the mean conditional probability that a student from 1972 in a given cell is admitted to a given college type during the respective survey wave. Application behavior is based on the top two school choices of respondents. Geography is according to the high school of the student. The test quintile comes from a survey-specific cognitive test battery given to the respondents of each survey during the spring of their senior year; by construction, it is normalized by cohort. (The test batteries are similar but not identical across surveys.) See the Data Appendix for the definitions of selective schools and the regional breakdowns. The covariates used for the regression include class rank decile dummy variables (GPA for 2004); categorical homework time dummy variables; region dummy variables; test quintile dummy variables; high school semesters each of English, math, social studies, science, and foreign languages; and participation dummy variables for each of sports, music/debate/drama, newspaper/yearbook, and student government. 
Appendix Table 4: NCES Longitudinal Student Datasets

\begin{tabular}{|c|c|c|c|c|c|c|c|c|}
\hline & \multicolumn{2}{|c|}{ NLS72 } & \multicolumn{2}{|c|}{ HSB82 } & \multicolumn{2}{|c|}{ NELS92 } & \multicolumn{2}{|c|}{ ELS04 } \\
\hline & $\begin{array}{c}\text { Un- } \\
\text { Weighted } \\
\end{array}$ & Weighted & $\begin{array}{c}\text { Un- } \\
\text { Weighted } \\
\end{array}$ & Weighted & $\begin{array}{c}\text { Un- } \\
\text { Weighted } \\
\end{array}$ & Weighted & $\begin{array}{c}\text { Un- } \\
\text { Weighted } \\
\end{array}$ & Weighted \\
\hline Female & $51.0 \%$ & $50.1 \%$ & $51.9 \%$ & $51.1 \%$ & $51.3 \%$ & $50.0 \%$ & $50.5 \%$ & $50.2 \%$ \\
\hline Black & $12.6 \%$ & $8.5 \%$ & $13.1 \%$ & $11.8 \%$ & $10.0 \%$ & $11.5 \%$ & $12.4 \%$ & $13.3 \%$ \\
\hline Hispanic & $4.5 \%$ & $3.3 \%$ & $21.4 \%$ & $12.2 \%$ & $12.6 \%$ & $9.9 \%$ & $13.7 \%$ & $15.1 \%$ \\
\hline Asian & $1.2 \%$ & $0.9 \%$ & $3.4 \%$ & $1.4 \%$ & $8.3 \%$ & $4.5 \%$ & $10.5 \%$ & $4.5 \%$ \\
\hline Native American & $1.1 \%$ & $1.0 \%$ & $1.9 \%$ & $1.1 \%$ & $1.1 \%$ & $1.1 \%$ & $0.8 \%$ & $0.9 \%$ \\
\hline White & $77.8 \%$ & $83.4 \%$ & $60.1 \%$ & $73.2 \%$ & $67.9 \%$ & $73.0 \%$ & $58.2 \%$ & $62.2 \%$ \\
\hline Mom: HS degree & $69.6 \%$ & $72.8 \%$ & $81.2 \%$ & $80.2 \%$ & $85.2 \%$ & $86.8 \%$ & $89.0 \%$ & $88.7 \%$ \\
\hline $\begin{array}{l}\text { Mom: College } \\
\text { degree }\end{array}$ & $10.7 \%$ & $10.6 \%$ & $14.1 \%$ & $15.6 \%$ & $26.1 \%$ & $26.0 \%$ & $29.7 \%$ & $26.9 \%$ \\
\hline Dad: HS degree & $64.9 \%$ & $68.7 \%$ & $76.9 \%$ & $77.1 \%$ & $84.0 \%$ & $85.8 \%$ & $88.4 \%$ & $87.9 \%$ \\
\hline $\begin{array}{l}\text { Dad: College } \\
\text { degree }\end{array}$ & $17.2 \%$ & $16.8 \%$ & $24.1 \%$ & $22.5 \%$ & $32.5 \%$ & $32.6 \%$ & $34.4 \%$ & $31.2 \%$ \\
\hline New England & $5.3 \%$ & $6.9 \%$ & $5.7 \%$ & $6.9 \%$ & $4.3 \%$ & $4.7 \%$ & $4.4 \%$ & $5.2 \%$ \\
\hline Middle States & $19.3 \%$ & $22.3 \%$ & $22.4 \%$ & $20.2 \%$ & $16.4 \%$ & $17.1 \%$ & $16.3 \%$ & $15.6 \%$ \\
\hline South & $21.9 \%$ & $16.4 \%$ & $16.7 \%$ & $18.5 \%$ & $21.4 \%$ & $22.1 \%$ & $25.3 \%$ & $23.3 \%$ \\
\hline Midwest & $28.3 \%$ & $31.3 \%$ & $28.1 \%$ & $29.5 \%$ & $27.2 \%$ & $26.7 \%$ & $26.0 \%$ & $25.2 \%$ \\
\hline Southwest & $8.9 \%$ & $6.9 \%$ & $9.8 \%$ & $9.4 \%$ & $11.1 \%$ & $10.7 \%$ & $8.4 \%$ & $9.1 \%$ \\
\hline West & $16.3 \%$ & $16.3 \%$ & $17.4 \%$ & $15.5 \%$ & $19.5 \%$ & $18.7 \%$ & $19.7 \%$ & $21.6 \%$ \\
\hline Observations & 15,635 & 3,043,599 & 11,189 & $3,161,622$ & 12,312 & $2,502,578$ & 13,370 & $2,983,515$ \\
\hline
\end{tabular}

Sources: NCES surveys, described in appendix text.

Notes: Numbers are percentages. Categories may not sum to 100 due to rounding and, for race, an omitted "other" category. Observations with zero or invalid (missing) weights were dropped. Race categories in ELS04 exclude the multiracial (about 4 percent of the student population). Education categories in HSB82 and NELS92 exclude those who report that they don't know their parents' education. 
Appendix Table 5: Composite Index of Competitive Pressure

\begin{tabular}{|c|c|c|c|c|c|}
\hline Rank & State & Index & Rank & State & Index \\
\hline 1 & New Jersey & 1.763 & 27 & Indiana & 0.876 \\
\hline 2 & Rhode Island & 1.736 & 28 & Wyoming & 0.847 \\
\hline 3 & District of Columbia & 1.708 & 29 & Alabama & 0.835 \\
\hline 4 & Connecticut & 1.608 & 30 & South Carolina & 0.826 \\
\hline 5 & Massachusetts & 1.551 & 31 & Tennessee & 0.824 \\
\hline 6 & New York & 1.512 & 32 & Wisconsin & 0.822 \\
\hline 7 & Delaware & 1.284 & 33 & Minnesota & 0.818 \\
\hline 8 & Virginia & 1.240 & 34 & Nebraska & 0.813 \\
\hline 9 & California & 1.204 & 35 & Maine & 0.800 \\
\hline 10 & Colorado & 1.160 & 36 & Ohio & 0.796 \\
\hline 11 & Georgia & 1.157 & 37 & Nevada & 0.794 \\
\hline 12 & Maryland & 1.055 & 38 & Washington & 0.766 \\
\hline 13 & Illinois & 1.045 & 39 & Oklahoma & 0.761 \\
\hline 14 & Florida & 1.034 & 40 & Kansas & 0.753 \\
\hline 15 & New Hampshire & 1.032 & 41 & Louisiana & 0.732 \\
\hline 16 & North Carolina & 0.993 & 42 & Montana & 0.727 \\
\hline 17 & Alaska & 0.987 & 43 & Mississippi & 0.702 \\
\hline 18 & Utah & 0.984 & 44 & Idaho & 0.676 \\
\hline 19 & Hawaii & 0.962 & 45 & Iowa & 0.673 \\
\hline 20 & Oregon & 0.955 & 46 & North Dakota & 0.671 \\
\hline 21 & Pennsylvania & 0.944 & 47 & New Mexico & 0.663 \\
\hline 22 & Kentucky & 0.939 & 48 & Missouri & 0.658 \\
\hline 23 & Vermont & 0.929 & 49 & West Virginia & 0.624 \\
\hline 24 & Texas & 0.902 & 50 & Arkansas & 0.482 \\
\hline 25 & Michigan & 0.893 & 51 & South Dakota & 0.398 \\
\hline 26 & Arizona & 0.884 & & & \\
\hline
\end{tabular}

Notes: The competitiveness index is the sum of the fractions of students doing each of the following five indicators in 1992: taking the PSAT, taking an AP exam, spending 10+ hours on homework per week, using private test preparation services, and sending 5+ college applications. Each indicator is taken from authors' calculations of NCES data, except for AP exam participation, which is from the College Board. 
Appendix Table 6: Sample summary statistics for Table 8

\begin{tabular}{|c|c|c|c|c|}
\hline Panel A: & $\begin{array}{c}\text { College } \\
\text { enrollment, } \\
\text { age } 19 \\
\end{array}$ & $\begin{array}{l}\text { Some college, } \\
\text { age } 25\end{array}$ & $\begin{array}{l}\text { Bachelor's } \\
\text { degree, } \\
\text { age } 25 \\
\end{array}$ & $\begin{array}{l}\text { Real earnings, } \\
\text { age } 25\end{array}$ \\
\hline Mean, top 6 states, 1980 & $54.4 \%$ & $62.1 \%$ & $29.5 \%$ & 22,648 \\
\hline Mean, top 6 states, 2006 & $74.8 \%$ & $72.1 \%$ & $39.7 \%$ & 16,570 \\
\hline Mean, other states, 1980 & $45.0 \%$ & $53.4 \%$ & $21.1 \%$ & 22,235 \\
\hline Mean, other states, 2006 & $65.6 \%$ & $65.9 \%$ & $28.7 \%$ & 16,870 \\
\hline Mean, top 11 states, 1980 & $50.8 \%$ & $58.6 \%$ & $26.5 \%$ & 22,152 \\
\hline Mean, top 11 states, 2006 & $71.2 \%$ & $68.5 \%$ & $34.7 \%$ & 16,542 \\
\hline Mean, other states, 1980 & $44.8 \%$ & $53.2 \%$ & $20.9 \%$ & 22,320 \\
\hline Mean, other states, 2006 & $65.5 \%$ & $66.1 \%$ & $28.7 \%$ & 16,914 \\
\hline Difference-in-difference, top 6 & -0.2 & -2.5 & 2.6 & -713 \\
\hline Difference-in-difference, top 11 & -0.3 & -3.0 & 0.4 & -204 \\
\hline Panel B: (per 1000 people) & All PhDs & $\begin{array}{c}\text { All science \& } \\
\text { engineering } \\
\text { PhDs }\end{array}$ & $\begin{array}{l}\text { PhDs from top } \\
\text { schools }\end{array}$ & $\begin{array}{c}\text { Science \& } \\
\text { engineering } \\
\text { PhDs from top } \\
\text { schools } \\
\end{array}$ \\
\hline Mean, top 6 states, 1972 & 8.3 & 3.9 & 1.7 & 0.9 \\
\hline Mean, top 6 states, 1995 & 1.1 & 0.8 & 0.4 & 0.3 \\
\hline Mean, other states, 1972 & 5.6 & 2.4 & 0.7 & 0.4 \\
\hline Mean, other states, 1995 & 0.6 & 0.5 & 0.2 & 0.1 \\
\hline Mean, top 11 states, 1972 & 7.7 & 3.7 & 1.4 & 0.8 \\
\hline Mean, top 11 states, 1995 & 1.0 & 0.7 & 0.7 & 0.3 \\
\hline Mean, other states, 1972 & 5.5 & 2.3 & 0.3 & 0.3 \\
\hline Mean, other states, 1995 & 0.6 & 0.5 & 0.1 & 0.1 \\
\hline Difference-in-difference, top 6 & -2.2 & -1.2 & -0.8 & -0.3 \\
\hline Difference-in-difference, top 11 & -1.8 & -1.2 & -0.5 & -0.3 \\
\hline
\end{tabular}

Note: Real earnings in Panel A are for current workers not enrolled in school and have been adjusted for sex, education, their interaction, and current state of residence. The 1995 values in Panel B are subject to data truncation (i.e., many people from the 1995 high school cohort have yet to earn a $\mathrm{PhD}$ ). 